\title{
Protecting Individual Self-Interest \\ IN Aggregate AS THE BASIS OF FAIRNESS IN CONTRACT
}

\author{
MATTHEW MARINETT*
}

\begin{abstract}
This article puts forward a unifying principle for the exceptions to contractual enforcement, including unconscionability, undue influence, duress, and mistake. In coming to a unified analysis, this article explains and defends three general premises. First, contract law should be understood as operating to maximize societal welfare in the aggregate. Second, contractual enforcement encourages and enforces welfare-enhancing agreements, but only if we can assume that each party is able to rationally consider her own self-interest. Third, agreements that were rationally welfare-enhancing when made should be enforced later even in cases of regret. Based on these premises, the analysis of unenforceability of unfair contracts can be reduced to two questions: whether, in the circumstances, parties to a contract were rationally able to consider and protect their self-interest, and, if not, whether the other side knew or ought to have known this.
\end{abstract}

\section{TABLE OF CONTENTS}

I. INTRODUCTION . . . . . . . . . . . . . . . . . . . . . . . . . . 704

II. THE NEED FOR A UNIFIED THEORY OF

EXCEPTIONS TO ENFORCEMENT $\ldots \ldots \ldots \ldots \ldots \ldots \ldots \ldots \ldots \ldots$

III. CONTRACT LAW AS

Welfare MaXimization in the AgGregate $\ldots \ldots \ldots \ldots \ldots \ldots \ldots . \ldots 710$

A. The Purpose of Contract LaW $\ldots \ldots \ldots \ldots \ldots \ldots \ldots \ldots$

B. CONCERNS WiTH UTILITARIAN AND

ECONOMIC AGGREGATION . . . . . . . . . . . . . . . 716

IV. UNIFYING DOCTRINES OF FAIRNESS BY

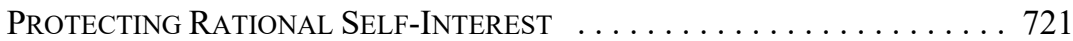

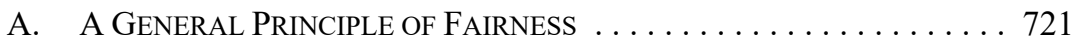

B. "RATIONALITY" AND "SELF-INTEREST" . . . . . . . . . . . . . 723

C. The Notice Rule: The Requirement of ACtual or Constructive Knowledge of the Non-Breaching Party . . . 727

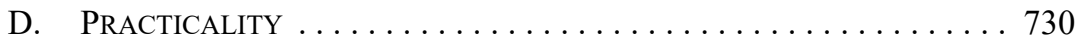

V. APPLYING THE UNIFIED APPROACH

TO EXISTING DOCTRINES OF FAIRNESS $\ldots \ldots \ldots \ldots \ldots \ldots \ldots \ldots \ldots$

A. Undue InFLUENCE $\ldots \ldots \ldots \ldots \ldots \ldots \ldots \ldots \ldots \ldots \ldots \ldots \ldots$

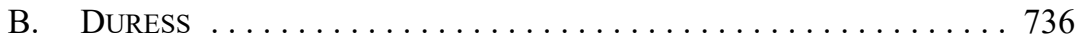

C. UnCONSCIONABILITY . . . . . . . . . . . . . . . . . . 738

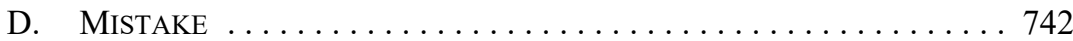

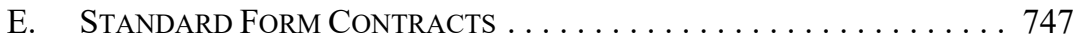

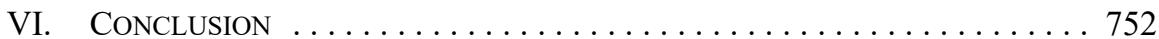

JD, LLM, SJD(c), University of Toronto. 


\section{INTRODUCTION}

Despite the existence of a near consensus on most of the specifics of common law contract law, ${ }^{1}$ there remains a great deal of uncertainty about the application of the doctrines of contractual fairness that serve to excuse a party from performance on the basis that the contract itself is unfair. ${ }^{2}$ As Stephen Waddams has put it, "no single principle has evolved to explain or to organize the cases." 3 This is perhaps not surprising given that doctrines of fairness work to excuse a party from enforcement of a contract, and there remains no generally accepted theory explaining why we enforce contracts in the first place. From Charles Fried's promise principle, ${ }^{4}$ to the consent-based theory of Randy Barnett, ${ }^{5}$ to those that propose that contract law seeks to improve societal welfare, ${ }^{6}$ the explanations for the enforcement of contract are as diverse as the doctrines they seek to explain. If we cannot agree on why contracts are enforced to begin with, it is understandable that we have difficulty identifying consistent principles under which a party can be excused from an otherwise valid agreement.

Unfortunately, the common law has become complicated by numerous exceptions to contractual enforcement on the basis of fairness that are inconsistently applied and which often conceptually overlap. ${ }^{7}$ The many exceptions to contractual enforcement on the basis of fairness include cases of unconscionability, undue influence, duress (including economic duress), mistake, and some exclusions that apply to standard form contracts. ${ }^{8}$ If we take

Peter Benson, "The Idea of a Public Basis of Justification for Contract" (1995) 33:2 Osgoode Hall LJ 273 at 276 [Benson, "Idea of a Public Basis"].

2 See SM Waddams, "Unconscionable Contracts: Competing Perspectives" (1999) 62:1 Sask L Rev 1 [Waddams, "Unconscionable Contracts"]; Stephen Waddams, Principle and Policy in Contract Law: Competing or Complementary Concepts? (Cambridge, UK: Cambridge University Press, 2011) at 87 [Waddams, Principle and Policy].

$3 \quad$ Waddams, Principle and Policy, ibid at 87.

4 Charles Fried, Contract as Promise: A Theory of Contractual Obligation (Cambridge, Mass: Harvard University Press, 1981).

$5 \quad$ Randy E Barnett, "A Consent Theory of Contract" (1986) 86 Colum L Rev 269.

6 See e.g. Anthony T Kronman, "Contract Law and Distributive Justice" (1980) 89 Yale LJ 472 at 472 75 [Kronman, "Contract Law"]; Charles J Goetz \& Robert E Scott, "Enforcing Promises: An Examination of the Basis of Contract" (1980) 89 Yale LJ 1261; Robert Cooter \& Thomas Ulen, "An Economic Theory of Contract Law" in Law \& Economics, 6th ed (Boston: Pearson, 2012) 276 [Cooter \& Ulen, "Economic Theory"]; Richard A Posner, "Wealth Maximization Revisited" (1985) 2:1 Notre Dame JL Ethics \& Pub Pol'y 85.

Waddams, Principle and Policy, supra note 2 at 87-122.

See Part IV.A, below. Note that I consider only those doctrines of fairness that excuse performance for a lack of fairness in the formation or terms of an agreement, rather than any excuses for nonperformance that may arise due to the failure of the other party to meet their express or implied obligations under the agreement. For this reason, issues of breach, including the recently recognized Canadian duty of good faith performance (see Bhasin v Hrynew, 2014 SCC 71, [2014] 3 SCR 494), are beyond the scope of this discussion. Some scholars also consider the increased scrutiny given to liquidated damages or penalty clauses to be a form of contractual fairness: see e.g. Mindy Chen-Wishart, "Controlling the Power to Agree Damages" in Peter Birks, ed, Wrongs and Remedies in the Twenty-First Century (Oxford: Clarendon Press, 1996) 271 [Chen-Wishart, "Controlling the Power"]; Tony Downes, "Rethinking Penalty Clauses" in Peter Birks, ed, Wrongs and Remedies in the Twenty-First Century (Oxford: Clarendon Press, 1996) 249. However, as it remains unclear whether the issue concerning penalty clauses is indeed a form of fairness, or whether other considerations motivate its existence, I exclude it from this article and leave it for consideration at another time. 
seriously the rule of law notion that the law should have the virtues of clarity, consistency, and stability, ${ }^{9}$ we should seek a resolution to this disorder.

This article attempts to reach a unifying principle for the exceptions to contractual enforcement for fairness based on the premise that, in order to find a unifying principle for why we provide exceptions to contractual enforcement, we must first determine why contract is enforced at all. The fairness exceptions to contractual enforcement can then be united by a principle that contracts should not be enforced where to do so would undermine the purposes of enforcing contract, or where the reasons for non-enforcement outweigh the reasons for enforcement.

This article follows the economic justification of contract law ${ }^{10}$ to argue that, as the purpose of the law of contract is to enable welfare-maximizing agreements generally across a polity, ${ }^{11}$ doctrines of fairness operate to excuse parties from contractual enforcement where it would otherwise undermine welfare maximization. This understanding is premised on the notion that contract law, as law of general application, ${ }^{12}$ must be understood at a societal and aggregative level, despite the law's iterative adaptation in response to individual disputes. This article then demonstrates that principles of fairness in contract are better explained by recourse to welfare maximization at an aggregative and societal level rather than by reference to utility maximization in any specific case. It argues that, on this basis, the various doctrines of fairness in contract, including undue influence, duress, unconscionability, and mistake, can be united in a singular analysis which explains the exceptions to enforcement as instances in which the rationale for contractual enforcement no longer applies. Thus, questions of contractual fairness can be reduced to a single inquiry into whether the parties could, in the circumstances of contract formation, rationally protect their own self-interest with respect to the terms of the agreement. Where they could not do so, the contract should not be enforced, as it would undermine the very purpose of contractual enforcement itself.

This article proceeds as follows. Part II of this article will review the current conceptual quagmire of the doctrines of contractual fairness and demonstrate the need for a principle that can unify them so that courts can apply a simplified and coherent analysis to questions of contractual fairness.

Part III of this article will develop the rationale for contract law from economic first principles to establish the following three premises: (1) the utility of contract law, as a stateLisa M Austin \& Dennis Klimchuk, "Introduction" in Lisa M Austin \& Dennis Klimchuk, eds, Private Law and the Rule of Law (Oxford: Oxford University Press, 2015) 1 at 3.

10 See e.g. Goetz \& Scott, supra note 6.

11 It should be noted that this article cannot, and will not attempt to, provide a complete theory of contract. Its purpose is instead to suggest that a theory that views contract law as a vehicle to protect rational selfinterest in aggregate across a society may assist in uniting the particular doctrines of fairness in contract law under a single analysis.

12 Lon Fuller and William Perdue raised the question of why contract should be enforced by state law in their famous article on the reliance interest in contract. See Lon L Fuller \& William R Perdue, Jr, "The Reliance Interest in Contract Damages: 1" (1936) 46 Yale LJ 52 at 57. 
enforced law of general application, should be judged on aggregative and societal level, rather than on its effectiveness in dealing with any given individual case; (2) contractual enforcement encourages and enforces welfare-enhancing agreements, but only if we can assume that each party is able to rationally consider her own self-interest with respect to the terms of the agreement such that both parties increase their utility in the bargain; and (3) agreements that are rationally welfare-enhancing at the time of their formation should generally be enforced even in cases in which one party later regrets the agreement, to protect the welfare-enhancing institution of contracting. This section will also address some alternative views and criticisms of these premises.

Part IV builds upon these premises to argue that fairness in contract is fundamentally about identifying those situations where one or more parties to a contract were not able to consider their rational self-interest with respect to the terms of the agreement. It suggests that courts, when faced with a claimant requesting excuse from their contractual commitments, inquire whether, in the circumstances, both parties were rationally able to consider and protect their interests in the formation of the agreement. Where both parties could not, the agreement should be set aside. Where only one party could not, the agreement should be set aside where the other party knew, or should have known, that the other party could not rationally consider and protect their own interests. This Part will also address what it means to protect rational self-interest with respect to the terms of an agreement by reference to utilitarianism and modern behavioural economics.

Part V will then establish how this rule can effectively explain, unify, and subsume the various doctrines of fairness, including the doctrines of duress and undue influence, mistake, and unconscionability, as well as provide an approach to addressing the deficiencies of consumer standard form contracts.

\section{THE NEED FOR A UNIFIED THEORY OF EXCEPTIONS TO ENFORCEMENT}

It might be asked why the author should bother attempting to unite the doctrines of fairness in contract. To the extent that these doctrines have achieved any sort of consensus about their functions and applications, one might suggest it is best to "leave well enough alone."

The problem, of course, is that there is no such consensus. The cases disclose no clear principle that gives the parties to an agreement any certainty about when a doctrine of fairness might be applicable ${ }^{13}$ except, perhaps, for the more obvious examples of duress. ${ }^{14}$ It is also unclear, even where a case might warrant the imposition of an exception for

Waddams, Principle and Policy, supra note 2 at 87.

See e.g. Barton v Armstrong, [1973] UKPC 27, [1976] AC 104 [Barton] (in which a contract was set aside for being made under threat of death). 
fairness, which such exception might apply. Indeed, it is often unclear whether there is any meaningful difference between some of the existing categories.

Consider the English case of Credit Lyonnais Bank Nederland NVv. Burch, ${ }^{15}$ in which the respondent, Burch, had offered her property as security on the debt of her employer's small business, in which she had no financial interest as a shareholder. She was informed by the appellant bank that she should obtain independent legal advice, and that the security she was offering was unlimited in amount and time. She agreed in writing that she understood this, and wanted to proceed without legal counsel. When the small business inevitably collapsed, the bank sought to enforce the security, but she claimed undue influence on the basis that she had a close relationship with her employer. The Court agreed with Burch, finding that it was not enough for the bank to have told her to get legal advice; instead, it should have ensured that she did. However, while the Court was adamant that the transaction was unfair, it proved more difficult to fit the finding of unfairness within the doctrine of undue influence. The relationship between Burch and her employer did not easily fall within the established categories of relationship giving rise to undue influence, such as that between husband and wife. ${ }^{16}$ Thus, it was incumbent upon Burch to prove that the relationship was one of trust and influence, which she could not do by direct evidence. However, the Court was willing to infer it from the onerous nature of the transaction. In doing so, the Court appears to have imported a notion of substantive unconscionability in order to find undue influence, with Lord Justice Millett even noting the substantial similarity between the two doctrines. ${ }^{17}$ From the perspective of the bank, which did not have actual notice of a relationship of trust and confidence between the employer and employee, this undoubtedly would have come as a surprise, and likely would have coloured their future practices with respect to such transactions. The law of undue influence being as unclear as it was led to an unfair agreement being made that the bank perhaps would not have made if it had known the state of the law, thus saving both parties from litigation and harm.

The broad doctrine of unconscionability is itself a subject of considerable debate, with uncertainty about the proper use of "procedural" or "substantive" unconscionability, or whether such a distinction is warranted. ${ }^{18}$

[1997] 1 All ER 144 [Credit Lyonnais].

There has been a considerable amount of scholarship, particularly from feminist scholars, on the issue of "sexually transmitted debt" cases - those cases in which a sexual or emotional partner, most often a woman, takes on responsibility for the other partner's debts or liabilities: see e.g. Belinda Fehlberg, "The Husband, the Bank, the Wife and her Signature" (1994) 57:3 Mod L Rev 467; Rosemary Auchmuty, "Men Behaving Badly: An Analysis of English Undue Influence Cases" (2002) 11:2 Soc \& Leg Stud 257; Janine Pascoe, "Wives, Business Debts and Guarantees" (1997) 9:1 Bond L Rev 58. However, this case differs somewhat from the paradigmatic sexually transmitted debt case in that the relationship was between an employer and an employee, and there was no evidence of a sexual or emotional relationship. While the issues raised by this line of scholarship may still be applicable, untangling the particular application of this literature is beyond the scope of this article.

Credit Lyonnais, supra note 15.

See e.g. Michael J Trebilcock, "An Economic Approach to the Doctrine of Unconscionability," in Barry J Reiter \& John Swan, eds, Studies in Contract Law (Toronto: Butterworths, 1980) 379 [Trebilcock, "Economic Approach"]; Waddams, "Unconscionable Contracts," supra note 2. 
Given the lack of uniformity in approaches to exceptions to contractual enforcement on fairness grounds, I suggest that the value of clarity in the law to both contracting parties and the public generally militates towards a need for a unifying principle. I do not expect this normative argument to be contentious, given that it is a generally accepted part of the rule of law. ${ }^{19}$ However, I discuss it briefly so its applicability to the issue of fairness in contract can be understood.

Clarity in the law is of considerable importance, especially when the law affects all those who have entered into or will ever enter into a contract, which we might expect is quite nearly the entire population of any common law country. Contract law is therefore not a specialist branch of the law designed only to be understood by, and apply to, a limited subset of society. Instead, it is a core example of a set of laws that we would expect to comply with the rule of law notion of clarity. Clarity underlies much of the other rule of law principles, such as that law must be able to be obeyed, that laws must not be contradictory, or that there must be congruence between stated law and official action. ${ }^{20}$ Without clarity in the law, it becomes impossible for the public to determine whether these other facets of the rule of law are being met. Instead, there might remain the fear that judges act arbitrarily or capriciously when deciding contractual fairness cases, undermining the institution of justice.

Perhaps more salient, however, is that the law of contract must be clear so that parties to a transaction can arrange their affairs with reasonable certainty that either the contract will be performed or that they will be entitled to a sufficient remedy. Without such an assurance by the law, the parties to the contract each bear the risk that the other party will breach the contract before performance in such a way as to disadvantage the non-breaching party. ${ }^{21}$ Indeed, as will be discussed in Part III, below, certainty in the enforcement of contractual relationships is the primary reason that contract law exists. With respect to the doctrines of fairness in contract, which go to the heart of contractual enforcement, certainty is a very real concern. Where it is unclear what might give rise to non-enforcement on fairness grounds, an innocent party may be surprised by, for example, an opportunistic claim of unconscionability or undue influence. The uncertainty of the principles of non-enforcement therefore builds extra risks into the contractual relationship that both parties must bear as costs. While no fairness principle can completely alleviate the risks of future litigation that parties bear at the time of contracting, a unified principle should provide sufficient certainty to allow parties to take low-cost steps to minimize it. An ideal principle would be clear enough that it prevents unfair contracts from being made in the first place, such as in the case of Lyonnais Bank, rather than merely providing ex post justification for non-enforcement. This ideal will be considered more in the development of the principle of contractual fairness in Part IV. 
Because a lack of coherence undermines certainty and increases the risk of contracting, a number of scholars have attempted to unify some of the doctrines of contractual fairness. ${ }^{22}$ Unfortunately, this has largely been done with respect to only a small number of the doctrines of contractual fairness, and without formulating a holistic analysis that can readily apply to all cases. Those views that have attempted to apply broadly typically focus on either a lack of "consent" on the part of the party claiming unfairness, or on the wrongdoing of the party seeking to enforce the contract. ${ }^{23}$ Both approaches are problematic.

The problem with the notion that fairness is about a lack of consent is that the argument becomes circular: the absence of "consent" merely becomes another way of saying that the contract was unfair. There are certainly contract cases where a contract is held unenforceable on fairness grounds despite consent, in the ordinary sense of the word, being expressly given. ${ }^{24}$ In Credit Lyonnais, for example, the respondent Burch had responded in writing to the bank's suggestion that she seek independent legal advice, and stated that she understood the agreement and wished to proceed. ${ }^{25}$ Nonetheless, the Court found she was under undue influence. To explain this through a lack of consent, "consent" needs to be reformulated into a complex notion that includes assessments of capacity and influence, arriving right back at the problem of what constitutes fairness.

The problem with looking at the wrongdoing of the party seeking enforcement is that it similarly stretches the notion of "wrongdoing" too far. Again, the case of Credit Lyonnais is a fitting example. The bank suggested repeatedly that Burch seek independent legal advice, and so far as it was concerned, it had done everything necessary to ensure the propriety of the transaction. If it engaged in any wrongdoing, it was that it entered the transaction with constructive notice of a possible relationship of influence. To call this "wrongdoing" is again to give content to the term that is not normally present, and requires an exegesis of wrongdoing within an overarching context of fairness.

See e.g. David Capper, "Undue Influence and Unconscionability: A Rationalisation" (1998) 114 Law Q Rev 479 (with respect to undue influence and unconscionability); Chen-Wishart, "Controlling the Power," supra note 8 (with respect to liquidated damages and unconscionability); SM Waddams, "Unconscionability in Contracts," (1976) 39:4 Mod L Rev 369 (with respect to duress, undue influence, unconscionability, penalty clauses, and others). 
As Mindy Chen-Wishart has argued, neither of these theories has sufficient explanatory power to make sense of what she calls the "clean cases," where the court finds neither wrongdoing on the part of the party seeking enforcement nor a lack of capacity on the part of the party seeking to escape enforcement. ${ }^{26}$

As there remains no satisfactory principle on which to unify the exceptions to contractual enforcement on fairness grounds, the following sections attempt to develop such a principle by understanding exceptions to enforcement on fairness grounds as situations in which the rationales for enforcing contract in the first place are no longer operating.

\section{Contract LaW as \\ Welfare MaXimization in the AgGRegate}

\section{A. The Purpose of Contract Law}

Before we can normatively justify exceptions to contractual enforcement, we must first understand why contract is enforced at all. Even if compelling reasons for non-enforcement are offered in a given case, logically they must be weighed against any deleterious effects that arise from non-enforcement. And we cannot fully appreciate any such deleterious effects unless we know why we have a general rule of enforcement in the first place.

The question, then, is why contract law exists. This question is not immediately concerned with the specifics of doctrines related to remedies or breaches, but rather asks why there should be any enforcement of an agreement through the action of law. To answer this question, this Part will advance three related premises, based on economic contract theory, that provide a strong rationale for the enforcement of contract by law.

\section{PRemise 1: Contract LaW Operates \\ ON AN AGgREGATIVE AND SOCIETAL LEVEL}

A starting point to determine the rationale for the enforcement of contract is to ask why law is the chosen enforcement mechanism, when other options exist. For example, if one is to argue that contract law is based upon moral imperatives, as Charles Fried did, ${ }^{27}$ then it is necessary to articulate a moral cause so pressing as to require legal intervention, where so many other matters of a potentially moral nature remain untouched by the law. Much is policed by societal approbation, reputational damage, business communities, informal arbitration, and many other mechanisms that operate outside of coercion by the law of the state. $^{28}$

Chen-Wishart, "Undue Influence,"supra note 23 at 237.

See Fried, supra note 4.

See William Twining, "Normative and Legal Pluralism: A Global Perspective" (2010) 20 Duke J Comp \& Intl L 473. 
Indeed, the law is a form of regulation that has several particularities. One such particularity (at least in societies largely deemed to be governed by the rule of law) is the notion that the law applies equally and broadly to all individuals within a polity. ${ }^{29}$ While, in the common law tradition, individual contractual cases may be determined by judges on a case-by-case basis, they do so both in a way that applies the existing law and is forward looking to the decision's effect upon the common law. ${ }^{30}$ The law is therefore developed not merely as a response to individual cases, but also in consideration of future cases. From the fact that the law of contract remains relatively stable and applies to all contractual commitments, we can conclude that the law of contract necessarily operates on a societal or aggregative level. ${ }^{31}$ To assert otherwise would require an explanation for why principles that are formed based on the interactions of specific parties should apply to all other parties, rather than deciding cases on a basis specific to those parties that may better adhere to the adjudicator's moral viewpoint. Even if we assume that there are cases similar enough that we would expect to reach similar conclusions, there are no grounds for precedent to provide anything more than persuasive authority.

Put another way, the argument is this: if there was only one contract ever made in all the world, and we can be certain that no other contract would ever be entered, should we apply modern contract law to that agreement? $?^{32}$ The answer to this question, I think, must be no. That which works best for one specific case may not work best for society when made a rule for all to follow.

Contract law is best seen as a public policy of contractual enforcement effected through the adjudication of "private" relationships. In their extremely influential article on the reliance interest, Fuller and Perdue recognized the tension between the notion that contract law is somehow "private" and its reliance upon public intervention through the institution of the courts. ${ }^{33}$ Indeed, the distinction between public and private law regained prominence only in the nineteenth century ${ }^{34}$ and has come under considerable scrutiny since at least the middle of the twentieth century. ${ }^{35}$ While the distinction may still be relevant for some

\section{Austin \& Klimchuk, supra note 9 at 3.}

30 The claim that judges generally consider the effects of their decisions upon future cases may be controversial, but I expect it to be true at least in many cases. See, for example, the discussion of developing the law made by Justice Sharpe in Jones $v$ Tsige, 2012 ONCA 32, 108 OR (3d) 241 at paras 65-69 [Jones] (recognizing the tort of intrusion upon seclusion in Ontario). This view also accords with Ronald Dworkin's conception of public reason, in which it is incumbent upon judges to "conceive the body of law they administer as a whole rather than as a set of discrete decisions that they are free to make or amend one by one": Ronald Dworkin, Law's Empire (Cambridge, Mass: Harvard University Press, 1986) at 167.

31 For a contrary view, see Benson, "Idea of a Public Basis," supra note 1.

32 Of course, there would be no contract law at all in such a world. But the question is whether it would make sense to apply the rules of our existing contract law to this hypothetical dispute.

Fuller \& Perdue, supra note 12.

Morton J Horwitz, "The History of the Public/Private Distinction" (1982) 130 U Pa L Rev 1423. While the distinction between public and private law existed in Roman law, it fell out of use during the medieval and enlightenment periods when the early common law was being developed. See Ariel Katz, "Intellectual Property, Antitrust, and the Rule of Law: Between Private Power and State Power" (2016) 17:2 Theor Inq L 633 at 649-50.

35 See e.g. Carol Harlow, "'Public' and 'Private' Law: Definition Without Distinction” (1980) 43:3 Mod L Rev 241; Duncan Kennedy, “The Stages of the Decline of the Public/Private Distinction” (1982) 130 U Pa L Rev 1349; David Dyzenhaus, "Liberty and Legal Form" in Austin \& Klimchuk, supra note 9, 92. 
purposes, and this article does not advocate the complete abandonment of the dichotomy, it does not deserve the central place afforded to it by some contract law theorists. ${ }^{36}$ To view contract as immune to issues of broad public policy is to miss much of what informs contract doctrine. Thus, we can conclude that the utility of contract law, as a state-enforced law of general application, should be judged on an aggregative and societal level, rather than on its effectiveness in dealing with any given individual case.

\section{PREMISE 2: CONTRACT LAW ENCOURAGES AND ENFORCES WELFARE-ENHANCING AGREEMENTS ASSUMING RATIONALLY SELF-INTERESTED PARTIES}

Premise 2 arises naturally from the adoption of the economic theory of contract. The economic perspective views contract as a mechanism to incentivize individual parties to enter coordinating agreements that, ideally, maximize both their own welfare and that of society broadly. ${ }^{37}$ This is fundamentally a conception of contract law that views contract as a mechanism for achieving Pareto superior ${ }^{38}$ distributions of goods, and enabling efficient and socially beneficial transactions. That is, the purpose of contract is to enable agreements that are in sum utility-increasing ${ }^{39}$ and to avoid game theory problems that would result in inefficient outcomes. ${ }^{40}$ Parties, under this theory, express their preferences at the time of contractual formation, which the law binds them to. This assumes that both parties have considered the terms of the agreement from a rationally self-interested perspective, ${ }^{41}$ and are therefore bargaining in such a way as to achieve a Pareto-superior transaction when viewed by the parties at the time of contractual formation. Proof of these preferences lies in the fact that these agreements were actually made, since each party would presumably not enter an agreement unless it at least appeared to promote her own interests. ${ }^{42}$ By binding parties to these initial preferences, the danger of one party defecting (not performing his end of the

See e.g. Peter Benson, "Misfeasance as an Organizing Normative Idea in Private Law" (2010) 60 UTLJ 731; Fried, supra note 4.

$37 \quad$ See e.g. Cooter \& Ulen, "Economic Theory," supra note 6.

38 A note on terminology: a transaction is said to be Pareto superior if at least one party is made better off while no parties are made worse off. By contrast, a transaction is Kaldor-Hicks efficient (a concept I refer to shortly) when the result is that those made better off by the transaction could compensate the losses of those made worse off while still retaining some surplus. Kaldor-Hicks efficiency does not require actually compensating the losing party, only that it be theoretically possible to do so. Pareto superiority, while attractive, is practically impossible to achieve in decisions or transactions that affect a large number of people, although it is common in voluntary exchanges between individuals. Almost all decisions at a societal level will involve making at least one person worse off.

39 Another note on terminology is necessary here, as there is a danger of confusion between the terms "welfare," "utility," and "wealth." I avoid using the term "wealth" in this article to refer to anything other than monetary wealth, so as to avoid the possibility that this article is only concerned with financial interests. However, "wealth" is frequently used in economics parlance to refer to the entire aggregate of one's rights, entitlements, and interests weighted by one's subjective valuation of each: Posner, supra note 6 at 85-88. However, I use welfare and utility somewhat interchangeably to mean something closer to a utilitarian conception of utility: See Jeremy Bentham, "An Introduction to the Principles of Morals and Legislation" in Kelly Rogers, ed, Self-Interest: An Anthology of Philosophical Perspectives (New York: Routledge, 1997) at 179-87.

$40 \quad$ See Cooter \& Ulen, "Economic Theory," supra note 6 at 283-87.

41 The notion of rationality in contractual decision-making is central to the reasons for its enforcement, and will be considered in greater detail in Part IV, below.

42 See e.g. Benson, "Idea of a Public Basis," supra note 1 at 284. 
bargain) after the other party has performed is mitigated, and reliance on contracts can be achieved.

Thus, assuming an economic viewpoint, we can reach the following simple premise: contractual enforcement encourages and enforces welfare-enhancing agreements, but only if we can assume that each party is able to rationally consider her own interests with respect to the terms of the agreement such that both parties increase their utility in the bargain. This last issue is taken up in Part IV, below.

\section{Premise 3: Agreements That Are WELFARE-ENHANCING AT FORMATION SHOULD BE ENFORCED EVEN IN CASES OF REGRET}

While it is easy to see the economic benefits of voluntary exchange and the importance of legally protecting the reliance interest in contract, it is less clear why contract law should protect the expectation interest, especially in cases of the purely executory contract (that is, a contract unperformed by both parties). This has long been a problem for contract theorists, ${ }^{43}$ but it is in resolving this problem that we can see the explanatory power of a theory that views contract as effecting aggregative welfare-maximization.

The traditional problem of the purely executory contract can be posed as follows: if one party decides they would like to exit the contract before any performance has been rendered, why not allow them to do so? In other words, why favour a party's preferences at the time of the contractual formation over their preferences at the time of breach, the latter of which are presumably better informed, or at least more current, than those at the time of formation?

Indeed, in an individual case, where one party later regrets an unperformed agreement due to a re-valuation of the promise, it may be more efficient (even Pareto superior) not to enforce the agreement if the revised valuations of the breaching party at the time of breach are significantly different from the valuations at the time of formation. ${ }^{44}$ However, a court cannot possibly determine the revised value of the promise to the breaching promisor. That the agreement was, in fact, initially made demonstrates that, at that time, it appeared beneficial to both parties. However, while the existence of consideration furnished evidence that both parties had made value determinations with respect to both mutual promises in the initial agreement, with no such clear evidence of a new valuation at the time of breach, the court has no reason to know whether enforcement or non-enforcement is more efficient as between the parties. The promisor has no reason to be honest about any new valuation. A court can logically take the breach itself as evidence that the promisor now places a higher value on the performance of the promise than the reciprocal consideration. It also knows that the promisee still values the promise more than the consideration offered in exchange

$43 \quad$ Ibid at 285; Fuller \& Perdue, supra note 12.

For a more detailed discussion of the problem of regret in purely executory contracts, see PS Atiyah, "Executory Contracts, Expectation Damages, and the Economic Analysis of Contract" in PS Atiyah, Essays on Contract (Oxford: Clarendon Press, 1986) at 158-66. 
because they brought an action aimed at achieving full performance of the agreement. However, the degree of utility gain or loss to either party through enforcement or nonenforcement is uncertain. It thus may or may not still be Kaldor-Hicks efficient to enforce (note that it can no longer satisfy the Pareto principle to enforce, because enforcement now appears to make the party seeking to escape the agreement worse off).

While this is highly indeterminate, other factors militate in favour of a general rule of enforcement to resolve this indeterminacy. The first is the lost opportunity cost of the promisee. Even if the promisee did not detrimentally rely on the promise, it may have lost opportunities to otherwise obtain what it would have received under the promise. These opportunity costs may or may not be calculable, and they may be great enough that the breaching party would prefer to perform if it was required to reimburse the other party for those lost costs. However, even if these costs can otherwise be recovered under a tortious restitution principle, they would only be calculable following significant investigation and administrative costs, and it is quite possible that they could not be adequately determined.${ }^{45}$ Additionally, through a general rule of enforcement, promisees are better able to further make contracts involving traded goods before actual delivery. As economic activity is presumptively welfare-enhancing (otherwise rational actors would not engage in it), by enabling additional market activity, distribution of goods to those who value them most is made more likely. A rule that favours non-enforcement in cases of regret necessarily impedes market activity that relies on a constant flow of goods through multiple economic actors. ${ }^{46}$ We can also expect that there will be welfare gains from the increased certainty that third parties can have in relying upon the completion of agreements between other economic actors under a rule of enforcement.

Finally, to fully appreciate the importance of looking at contract law at a societal level, we must consider the incentive impact of a rule against enforcement of purely executory contracts. As far as parties to an agreement would be concerned, an unrelied-upon and unperformed agreement would then be worth little to the parties, and certainly not worth the transaction costs of negotiation, since it would lack legal enforceability. Instead, the incentives might encourage enterprising parties to use contracts as a form of hedging, in which they enter as many future performance contracts as possible and either perform or renege at the time of performance based upon their preferred outcome at that time (assuming that the other party has not already performed or detrimentally relied upon the agreement). Parties that instead desire certainty in their contractual arrangements would therefore be incentivized either to only enter agreements at the time they were ready to perform, or to make reliance upon the agreement as quickly as possible in order to deter breach (on the basis that the breaching party's legal costs plus its payment of damages for reliance would be sufficient to deter breach). Either of these scenarios is unlikely to be welfare-enhancing if practiced widely in society. There is obvious utility in being able to arrange one's affairs 
in advance, and where the parties are incentivized to rely immediately upon an executory agreement, this is likely to result in a sub-optimal arrangement of affairs.

We can conceptualize this by imagining whether substantial manufacturing or development projects could be completed without the contractual certainty of expectation damages for purely executory contracts. Consider the final manufacturer of a product (say, a car) that must contractually arrange for the supply of materials and parts from numerous other suppliers and contractors before they can begin to sink costs into manufacturing themselves. Should those contractors or suppliers be able to escape their agreements cheaply before any performance is rendered or before the final manufacturer has begun production themselves, it may effectively derail large projects and have downstream impacts on other subcontractors or suppliers if the project is cancelled or redesigned in response. It may also result in a flurry of societally-destructive opportunism, with contractors regularly reneging on their arrangements in favour of better deals. We might expect that this could significantly hamper overall production and lead to firms inefficiently internalizing all steps of development.

Because of these considerations, a rule of enforcement is more likely to be welfareenhancing across a polity than not. While enforcement in any particular given transaction may or may not be welfare enhancing, at a societal level, a rule of enforcement in the otherwise indeterminate cases of regret is more likely to be beneficial than a rule that denies enforcement. ${ }^{47}$ Thus, on average and across a large number of cases, a utility gain is achieved.

Naturally, in cases of regret in purely executory contracts, enforcement of contract will be at best Kaldor-Hicks efficient as between the parties, and the party seeking to escape enforcement will likely be an uncompensated loser. However, we might expect that such individual losses will be compensated by the general societal benefits enjoyed by virtue of a system of contractual enforcement (as in the aphorism, "the rising tide lifts all boats"), and by the observation that, in the long run, equally-situated contracting parties are likely to suffer as many gains as losses through a rule of contractual enforcement. ${ }^{48}$ This remains true so long as specific parties are not systematically preferred over others so as to create consistent winners and losers. ${ }^{49}$ In this way, contract law achieves something closer to a Pareto superior outcome, even if it does not completely satisfy the Pareto principle in that

$47 \quad$ This argument also allows us to rebut the challenges to expectation damages raised by Patrick Atiyah. Atiyah argues that a rule of expectation damages and legal liability results in ambiguous utility in individual cases. However, he fails to consider the systemic efficiencies of legal liability, and he expressly avoids dealing with the question of opportunity costs. See Atiyah, supra note 44.

48 For more detailed explanations and examples of how the Pareto principle can be satisfied in the long run, see Richard A Epstein, "Nuisance Law: Corrective Justice and Its Utilitarian Constraints" (1979) 8:1 J Leg Stud 49 at $83-85$.

49 Contract law, in my view, should guard against systemically disadvantaging individual parties or identifiable groups. This might be achieved, at least in part, by applying the test formulated in Part IV of this article. However, a more fulsome discussion of how and when contract law might create systemic disadvantages to certain parties is outside the scope of this article. 
there may still be some unlucky losers not sufficiently compensated by the rising tide or their own contractual wins.

However, the argument can be summarized by asserting that contract is an efficient societal institution, and thus it is welfare-enhancing to maintain the institution even if it produces some inefficient results in individual cases. Thus, we reach our third premise that agreements that are rationally welfare-enhancing at the time of their formation should generally be enforced, even in cases in which one party later regrets the agreement, to protect the welfare-enhancing institution of contracting.

I now turn to some potential problems with this understanding of contract law and its resulting premises.

\section{B. CONCERNS WiTH UTILITARIAN AND ECONOMIC AgGREgation}

\section{SCOPE OF AGGREGATION AND SUBJECTIVITY OF UTILITY}

Utilitarianism generally aggregates utility across some number of individuals, summing the total of the change in their individual utility to determine whether an action is right or wrong. When we talk about the aggregation of utility or welfare as the basis of contract law, it is natural to ask what individuals are included in the calculus and across what time frame. The answer to this question is rather straightforward: whatever is reasonably foreseeable. Utilitarianism does not demand perfection in the predictive faculties of moral agents. ${ }^{50}$ In the case of contract law, we might say that the aggregation works across the jurisdiction of the courts applying the rules and into so far a future as we can reasonably predict, which I suspect is not very far. But these problems do not matter in practice. It is not as though through contract law we are making some trade-off where we lose now to gain more later, or where we penalize some geographically-defined group to the benefit of some other. Such concerns may arise in other contexts, such as whether we decrease our quality of life now to prevent the destruction of the environment for future generations. But this is not the case with contract. Contractual enforcement makes no such temporal or spatial trade-offs, as it applies at an atomistic level and equally across those subject to it. The institution of contract also, so far as I am aware, does not have externalities which would injure those in any foreign jurisdiction in which contractual enforcement does not exist. We can therefore expect that the enforcement of contract will increase welfare across any group of people and timeframe sufficiently large enough for the average observed result of enforcement to converge towards the theoretical mean. ${ }^{51}$ Given the prodigious rate of contract formation, this

See John Stuart Mill, Utilitarianism (Kitchener: Batoche Books, 2001) at 25.

In other words, the number of litigated cases must be large enough for the aggregative assumption to apply. If contract law were to apply only to a small group of individuals, we cannot be sure that it would result in welfare gain, even if the expected result of enforcement, on average, is a gain. This can be analogized to rolling a die. The expected result of rolling a standard six-sided die many times is an average result of 3.5 . However, if we roll the die once, it is just as likely to be a one as a six, and it 
timeframe need not be very long. Thus, for the purposes of this article, these concerns are of little consequence.

A second potential problem is the subjectivity of utility. Each individual defines her own utility in choosing her purposes, her happiness, and the situation of her general well-being. ${ }^{52}$ How, then, can we know that any given act makes anyone better off when we cannot know what makes them better off?

Again, here, the particular nature of contract helps us escape this apparent conundrum. ${ }^{53}$ Contract law is concerned with allowing individuals to achieve their own ends rather than attempting to choose their ends for them. Utility may be subjective, but contract law serves to protect the institution of exchange that allows the individual to achieve her own purposes and raise her own subjective utility. With only limited exceptions, ${ }^{54}$ contract law does not apply discriminatorily to the exchange of only certain goods and services, and thus it does not generally preference certain ends over others. Instead it, as Henry Sidgwick says, helps the individual "promote his own happiness better than he would without interference." 55 That interference would come from a situation of frequent contractual breach and opportunism that might exist without contract law.

Thus, in a discussion of contract law, the issue of the subjectivity of utility tends to promote the implementation of contract law rather than undermine it, as contract law is aimed at protecting the autonomous pursuit of individual happiness rather than guiding it in a particular direction.

\section{INABILITY OF COURTS TO MAKE DECISIONS ON GROUNDS OF PUBLIC POLICY}

As this discussion makes clear, under the rule utilitarian view of contract law, the purpose of contract law is not aimed at corrective justice. Indeed, I adopt a view, similar to that articulated by Anthony Kronman, ${ }^{56}$ that contract law's aim is inherently distributive. This is a necessary implication of contract law's societal operation. Contract law, in part, facilitates the movement of goods towards those who most highly value them, while at the same time preventing economically costly advantage-taking. We can therefore conclude that the

certainly will not be 3.5. To get the observed average result to converge towards the expected average of 3.5 , we must roll the die many times.

52 See Henry Sidgwick, The Elements of Politics, 2nd ed (London: Macmillan \& Co, 1897) at 40-41.

53 It is not really a conundrum. Individual utility functions do not vary so greatly as to be completely unpredictable, at least with respect to fundamental matters. For example, we can assume that people would rather be fed than starve, rather have money than not, and rather have friends than be alone. Where utility functions do vary greatly, such as with respect to the appreciation of art or the choice of profession, actions that promote individual choice should be preferred. See Sidgwick, ibid.

Contract is notably not enforced in illegal markets. For a more fulsome discussion of this nonenforcement, see Adam B Badawi, "Harm, Ambiguity, and the Regulation of Illegal Contracts" (2010) 17:2 Geo Mason L Rev 483 at 483. For a discussion of various types of illegal markets, and the goods and services transacted on these markets, see Jens Beckert \& Frank Wehinger, "In the Shadow: Illegal Markets and Economic Sociology" (2013) 11:1 Socio-Economic Rev 5. 
promotion of economic activity and the prevention of losses will outweigh the inherent uncertainty in whether enforcing a given contractual relationship in the case of regret results in an efficient outcome as between those parties.

The foregoing implicates a response to a criticism regarding aggregative or distributive theories generally. This criticism worries that, for such theories:

The only stable, non-arbitrary stopping point is the analysis of welfare changes across the public as a whole via innumerable, unidentified, individual transactions, and over an indefinite period of time. But to suppose that any institution, let alone a court, could make this determination is implausible. In other words, Kronman's distributive analysis does not readily lend itself to decision-making in a public institutional setting. It certainly does not fit within the limits and presuppositions of common law adjudication of twoparty disputes. 57

What this criticism overlooks, however, is that this type of broad determination is precisely the only kind of determination that the law of the state is capable of making. Is the law of tort, for example, not meant to apply across innumerable, unidentified, individual interactions for an indefinite period of time, despite its application to individual parties? If not, to whom is it to apply?

Judges and the law must here be differentiated. A judicial decision is but one tiny strand of a much larger and evolving web that forms the common law, whose only possible purpose is to apply to innumerable, unidentified, individual transactions over an indefinite period of time. An individual judicial decision on its own may or may not be just, may or may not be principled, may or may not be persuasive, and may or may not be followed in other similar cases. While judges may, and should, turn their attention to the effects of their decisions beyond an individual case before them, it is not incumbent upon a judge to articulate a perfectly efficient rule of broad application. The common law allows for error correction, and even experimentation. In other words, it evolves. ${ }^{58}$ If we accept that the common law, therefore, has any social function whatsoever, it must be to apply across such a breadth of transactions and time. There is no reason to believe that the law of contracts is different.

\section{COERCION OF THE INDIVIDUAL FOR THE Purposes of Societal Welfare}

This leads to another important question, which is how an aggregative principle can justify coercion of the individual against that individual's wishes. ${ }^{59} \mathrm{My}$ answer to this question is a rather simple one: law coercively imposes many obligations upon individuals, both positive and negative, and contract should be treated no differently. To question the power of the state to coercively enforce contracts is to question its power to coercively impose taxes,

Benson, "Idea of a Public Basis," supra note 1 at 304.

See e.g. Jones, supra note 30 ("[i]t is within the capacity of the common law to evolve" at para 68).

This question is a profoundly important one, but as it leads to a deeper discussion of political theory outside the scope of this article, I must deal with it in a brief, and likely unsatisfactory, manner. 
criminalize the possession of powerful weapons, or mandate jury duty. It is to question the foundation of law. Ultimately, the justification for such state coercions is found in the social contract. As a society, we choose such welfare-enhancing coercions because we recognize that generally, we are better off for them. ${ }^{60}$ We recognize that the non-enforcement of contract would be so destabilizing that not even moral approbation is sufficient to deter it; the law must step in. By enforcing contract, the government is exercising the very function that justifies its existence. ${ }^{61}$

\section{ECONOMIC ASSUMPTIONS AND HUMAN BEHAVIOUR}

Another criticism focuses on the broad assumptions made by many economic theorists that are not borne out by practical experience. ${ }^{62}$ One such assumption is that contracts are always made rationally, and that contracting parties are the best judges of their own interests. ${ }^{63}$ Because of this assumption, Atiyah argues, economic theorists often erroneously attack laws designed to protect disadvantaged parties by limiting or prohibiting certain exercises of contractual freedom. ${ }^{64}$

I do not challenge these criticisms, but I do not think that they are fatal to economic theories generally. Rather, they are fatal to particular economic analyses that are built upon faulty assumptions. These criticisms of economic assumptions, such as the assumption that economic actors behave rationally, have been common even from within the law and economics community. ${ }^{65}$ Indeed, behavioural economics, while in its early stages, can be seen as a reaction to these criticisms. ${ }^{66}$

I proceed in this article fully cognizant that economic analysis may be prone to unfounded generalizations, and that laws that push individuals towards making certain choices are not necessarily incongruent with economics once the realities of human behaviour are

One can make this argument through any contractarian theory. For example, it makes sense that we would choose such generally welfare-enhancing public law coercions if we adopt the original position of John Rawls, in which each person must choose their societal order behind a veil of ignorance that prevent them from knowing any of the details of their eventual station in life. See John Rawls, A Theory of Justice, revised ed (Oxford: Oxford University Press, 1999) at 102-30. More naturalistic contractarian theories can also be appeased by reference to the observation that modern democratic societies choose many of these public law coercions with little dissent.

This point is similar to the purpose of the social contract identified by John Locke. He argued that "[t]he great and chief end" of men forming a commonwealth was the preservation of their property through coercive law: John Locke, Second Treatise of Government (1690), s 124. Henry Sidgwick also made this point in his influential utilitarian political treatise The Elements of Politics when he states that "the community has, in my view, an indisputable right to impose on its members the observance of whatever rules it is conducive to the general happiness that they should be made to observe": Sidgwick, supra note 52 at 646 . Indeed, it is on a similar utilitarian basis to the one described here on which he justifies contractual enforcement.

Ibid.

See e.g. Grand M Hayden \& Stephen E Ellis, "Law and Economics After Behavioral Economics"(2006) 55 Kan L Rev 629 (reviewing the many criticisms of the assumptions of law and economics at 636-40). See generally ibid. 
considered ${ }^{67}$ Indeed, as the economic theory of contract relies upon the ability of parties to rationally protect their own interests, this article argues that contract law should endeavour to enforce agreements only where the parties appear capable of protecting their rational selfinterests with respect to the terms of the agreement. I address the behavioural economics approach to human rationality in Part IV, below.

\section{Collapse OF RUle Utilitarianism INTO ACT UTILITARIANISM}

It should now be clear that my conception of the law is one close to rule utilitarianism, which holds that an act is right if it conforms to a rule (the law) that brings about the most societal welfare. This brings me to another important, if only theoretical, contention: that a rule utilitarian theory of contract will, in the process of constantly undergoing modifications necessary to ensure efficient outcomes in individual cases, collapse into act utilitarianism. ${ }^{68}$ The argument goes that, under rule utilitarianism, so many individual rules will be made to ensure a best all-things-considered outcome in each case that the result will be the creation of as many rules as there are cases. This, in effect, is no different from act utilitarianism.

The problem with this argument is that an institution of rule utilitarianism may itself be the result of an act utilitarian analysis. We generally regard the rule of law as a social good for reasons of practicality and fairness. ${ }^{69}$ Providing confidence that contracts will be enforced, and will not be defeated by unknowable ex post facto considerations, is central to the entire purpose of contract law. Therefore, using a set of rules of general application in the form of laws serves an act utilitarian purpose, despite the law itself attempting to achieve rule utilitarian goals. Indeed, the collapse of the law into act utilitarianism should, if the law of contract is to have any value, be prevented on act utilitarian grounds. ${ }^{70}$

John Rawls made a similar point in his article "Two Concepts of Rules." argued that when dealing with institutions, we must be cognizant that the design and purpose of the institution may be utilitarian even if the individual rules or decisions promulgated by that institution are not. ${ }^{72}$ It can be utilitarian to deny utilitarian arguments to individuals when utility requires certain societal rules of general application. ${ }^{73}$ Thus, when looking at cases of contractual breach, we must look not only to the individual utility of non-enforcement as

This argument has been made at length by Professors Thaler and Sunstein: see Richard H Thaler \& Cass R Sunstein, Nudge: Improving Decisions About Health, Wealth, and Happiness (New Haven: Yale University Press, 2008); Richard H Thaler, Misbehaving: The Making of Behavioral Economics (New York: W W Norton, 2016).

Charles Fried, for example, made this argument in Contract as Promise. See Fried, supra note 4 at 16. Fried is somewhat more accommodating to economic and utilitarian views in the second edition of Contract as Promise, although he retains this argument: see Charles Fried, Contract as Promise: A Theory of Contractual Obligation, 2nd ed (Oxford: Oxford University Press, 2015) at 16. See e.g. Raz, supra note 19.

70 It should be noted that Charles Fried did briefly address this defence of act utilitarianism, although his response was evasive. He stated that he was concerned with the question of individual obligation, and therefore a utilitarian theory applied to legislators did not concern him. See Fried, supra note 4 at 16. John Rawls, "Two Concepts of Rules" (1955) 64:1 Philosophical Rev 3.

Ibid at 7-9.

Ibid at 16 . 
between the parties, but also the effect such a decision would have on the institution of promising generally. ${ }^{74}$ It is only by considering contract law as such a societally operative institution that its doctrines can be understood.

\section{UNIFYING DOCTRINES OF FAIRNESS by Protecting Rational Self-Interest}

\section{A. A General Principle of Fairness}

Fairness in contract has proved a difficult problem for commentators of all theoretical bents and for the courts. ${ }^{75}$ If we accept that the general enforcement of contract serves a useful purpose, then it can be challenging to explain why the courts should so frequently ${ }^{76}$ choose to find that an agreement is unenforceable on the basis that the contract is itself unfair.

The legal grounds for unfairness also happen to be somewhat numerous. ${ }^{77}$ Duress, including economic duress, and undue influence form perhaps one conceptual category in which it is claimed, typically, that consent to the agreement was vitiated by the influence of the other party, or a third party. ${ }^{78}$ Another is unconscionability, a conceptually difficult exception under which courts generally look to see whether an agreement was substantively unfair, in that the terms are such as could not be reasonably agreed to, and procedurally unfair, in that the circumstances surrounding the formation of the contract suggest a disparity of "bargaining power" (a troublesome term) or an advantage-taking by one party. ${ }^{79}$ Mistake may well be another category of excuse on contractual fairness grounds. ${ }^{80}$ Finally, the fairness of standard form contracts has attracted much scholarly attention, and they might too be candidates for non-enforcement on this basis. ${ }^{81}$

Despite the multitude of contractual doctrines, as discussed above in Part II, some commentators have suggested that some, or all, of these doctrines can be combined to form a more cogent approach to fairness in contract. ${ }^{82}$ This article takes up this argument, using the theory of aggregate welfare maximization to attempt to explain how each of these

Ibid at 14 .

For a discussion of this difficulty, see Waddams, "Unconscionable Contracts," supra note 2.

Ibid at 1.

Again, I exclude any issues of breach from this analysis, as well as the issue of penalty clauses. See supra note 8 .

See e.g. Allcard, supra note 24.

Waddams, "Unconscionable Contracts," supra note 2 at 3.

Waddams suggests, for example, that one court's refusal to enforce an undisclosed clause that limited insurance coverage in a standard form contract in the case of Tilden $v$ Clendenning (1978), 18 OR (2d) 601 (CA) may be better conceived of as a case of mistake than of unconscionability. See ibid at 3 .

${ }_{81}$ See e.g. Margaret Jane Radin, Boilerplate: The Fine Print, Vanishing Rights, and the Rule of Law (Princeton: Princeton University Press, 2013); W David Slawson, "Standard Form Contracts and Democratic Control of Lawmaking Power" (1971) 84:3 Harv L Rev 529; K N Llewellyn, Book Review of The Standardization of Commercial Contracts in English and Continental Law by O Prausnitz, (1939) 52:4 Harv L Rev 700; Todd D Rakoff, "Contracts of Adhesion: An Essay in Reconstruction" (1983) 96:6 Harv L Rev 1173.

82 See supra note 22 and accompanying text. 
exceptions to enforcement can be justified on this basis, and how they can all be united into a singular analysis.

My approach follows from the three premises established in Part III of this article: (1) the utility of contract law, as a state-enforced law of general application, should be judged on an aggregative and societal level, rather than on its effectiveness in dealing with any given individual case; (2) contractual enforcement encourages and enforces welfare-enhancing agreements, but only if we can assume that each party is able to rationally consider her own interests with respect to the terms of the agreement such that both parties increase their utility in the bargain; and (3) agreements that are rationally welfare-enhancing at the time of their formation should generally be enforced, even in cases in which one party later regrets the agreement, to protect the welfare-enhancing institution of contracting.

It follows from the second premise that there is no reason to enforce a contract where one or more parties to the agreement appears to have been unable to rationally consider and protect their own self-interest with respect to the terms of the agreement, as this undermines the assumption that contracts are welfare-enhancing agreements. From the first and third premises, we can conclude that courts should only excuse parties from otherwise complete agreements based upon general rules or principles that supply sufficient certainty to contracting parties such that they do not undermine the utility of the institution of contract.

On this basis, we can establish the following principle. Where both parties were unable to rationally consider their own self-interest with respect to the terms of the agreement at the time of formation, the agreement should be voidable on the basis that the entire premise of contract is eliminated. In the more likely case of only one party having been unable to do so, the agreement should be voidable by that party only by the application of a rule that ensures certainty of contract will not be undermined. On this basis, I propose a simple rule that, as I will discuss, appears to accord well with existing doctrines of fairness. That rule is that a party should only be able to escape a contract on fairness grounds where the other party knew or should have known that she was not able to consider her self-interest with respect to the terms of the agreement. This last element, I refer to as the "notice rule," and I will discuss it in greater detail below.

Of course, there is nothing inherent in this principle to suggest that it can unify the doctrines of fairness. It clearly suggests a number of circumstances where contract should not be enforced, but it does not follow that it necessarily covers all of the situations to which doctrines of contractual fairness apply. It may well be that some of these fairness doctrines exist for reasons that go beyond mere respect for the purposes of contractual enforcement, and instead, for example, import outside public policy concerns, or address issues not internal to contract law. While this is logically true, as I demonstrate in the next Part, the principle does appear to have explanatory power for the doctrines of fairness. Thus, it serves as an elegant device to subsume them into a single analysis. 
However, before proceeding, in the next Part, to demonstrate how it can unite the existing doctrines of contractual fairness, I first turn to flesh out the elements of this principle of fairness.

\section{B. "RATIONALITY" AND "SELF-INTEREST"}

The reader would be forgiven for wondering what it means for an individual to rationally consider her own self-interest, as it is inherently mired in some ambiguity. The phrase obviously requires a discussion of each of its primary elements, the first being the nature of rationality and the second being the nature of self-interest. As the second of these is amenable to a more concise discussion based upon utilitarian premises, I begin with it.

\section{SELF-INTEREST}

The notion of self-interest is a familiar one to utilitarian moral philosophers. For Jeremy Bentham, self-interest is the core of utilitarian theory. ${ }^{83} \mathrm{He}$ rejects the notion that people could be inherently altruistic or concerned with the well-being of others; what appears as altruism is often the mitigation of personal pain experienced through the faculty of empathy, or a desire for companionship or reward. ${ }^{84}$ For him, utility is self-interest manifested in pleasure or pain, although he uses the terms "pleasure" and "pain" to refer broadly to larger concepts of the experience of personal well-being, or the lack thereof. The "interest" with which self-interest is concerned is thus the increase in the sum total of the self's pleasures (or, in the same way, the reduction of pains). ${ }^{85}$ For Bentham, as for other utilitarian theorists, ${ }^{86}$ utility is inherently subjective, and that which is conducive to the happiness of one individual is not necessarily conducive to the happiness of another.

Thus, when I use the term "self-interest" or "one's own interests" in this article, I mean only what might be understood in an ordinary sense: that is, whatever serves to promote the individual happiness and welfare of that particular person. The notion does require some clarification, in order to avoid the obvious criticism that what makes an individual happier now may make him miserable in the future. Thus, when speaking of happiness or welfare, I refer to the sum total of happiness or welfare across the lifetime of the individual, so far as this can be foreseen, rather than over any shorter or indefinite time period.

As I have already discussed, contract law tends to promote personal welfare by protecting exchange that is presumptively welfare enhancing. Regardless of the nature of the exchange, any exchange that is actually made absent external coercion or influence must, from the perspective of the parties, apparently increase personal welfare over the alternative course of action, which is to not enter into the agreement. Otherwise, there can be no motivation that would make an individual enter into the agreement. This is true even if the exchange is not 
rationally likely to promote that self-interest. In such cases, we cannot expect the agreement to be welfare-enhancing, as there is an obvious disconnect between purposes and effects. As the purpose of contract is to enable the rational pursuit of self-interest, it therefore makes little sense to enforce contract where the pursuit of self-interest through contract cannot be said to be rational.

\section{RATIONALITY}

Rationality stands at the heart of both the reason for the enforcement of contract and, as this article argues, the reasons we should excuse parties from an agreement. An agreement is only likely to be mutually welfare-enhancing if the parties to it are able to rationally consider their own interests and make an agreement that, reasonably, can be expected to promote those ends. Looked at this way, a "rationally" self-interested choice is one that is likely, based upon present circumstances, to lead to an improvement in personal utility (that is, personal welfare or happiness).

If we observed, for example, that market actors tended to enter absurd or random agreements, contractual enforcement could not be justified. That this is not the case should be obvious, but what is less obvious is where the line ought to be drawn, for the purposes of contractual enforcement, between the subjectivity of personal utility and a definite notion of irrationality. The assumption of classical economics has long been that individuals are essentially rational in their choices and these choices can be predicted based upon the expected final state of an individual's utility function after the choice.$^{87}$ But as the utility function is subjective, economists assumed, based upon the premise that individuals behaved rationally, that individual utility functions could be determined empirically from their choices in exchange. ${ }^{88}$ For example, if Alice trades an apple to Bob in exchange for an orange, assuming they are both rational, we gain some information about each party's utility function: Alice values the orange more than the apple, and the converse is true for Bob.

The problem with this approach is that psychologists have demonstrated that people, in situations of choice and exchange, do not always behave rationally. ${ }^{89}$ People frequently use a number of decision-making heuristics (shortcuts or rules of thumb), or display biases that lead to decisions that either do not result in an increase in utility or which do not maximize utility based upon the available choices. These heuristics and biases are numerous, and the evidence has shown that they are pervasive and can have substantial negative effects upon both individual welfare and society. ${ }^{90}$ For example, people tend to be poor planners and take Amos Tversky, "Prospect Theory: An Analysis of Decision Under Risk" (1979) 47:2 Econometrica 263 at 263-64.

88 Robert Cooter \& Thomas Ulen, Law and Economics, 5th ed (Boston: Pearson, 2008) at 22-24. See also Benson, "Idea of a Public Basis," supra note 1 at 284.

89 See generally Daniel Kahneman, Thinking, Fast and Slow (Toronto: Anchor Canada, 2013).

90 See generally ibid. 
an overly optimistic view of future events. This can explain why cost overruns on large capital projects are common, ${ }^{91}$ or why many people save too little for their retirement. ${ }^{92}$

The rise of the behavioural economics movement has been heavily influenced by these developments from the realm of psychology. ${ }^{93}$ Unfortunately, behavioural economics neither offers a solution to human irrationality, nor a reliable way to introduce irrationality to predictive models. ${ }^{94}$ That does not mean, however, that there are not some things that can be done to limit the effects of irrationality, or that human rationality is so unfixable as to warrant complete supervision of individual decisions. This is why behavioural economists refer to humans as exhibiting "bounded rationality,"

Indeed, the observed impact of biases and heuristics on decision-making can be reduced by slowing down and carefully reflecting on the decision, and by recognizing one's own biases. ${ }^{96}$ This, of course, is not a complete cure, and individuals will sometimes need help ensuring that they do so. The law has already, in some cases, addressed the danger of decisions made quickly, especially in high pressure situations. For example, with respect to contracts, the consumer protection law of some jurisdictions prescribes cooling off periods (during which the consumer can escape the contract) on contracts made via door-to-door sales. ${ }^{97}$ This can be seen as an example of what Thaler and Sunstein call "libertarian paternalism": legal mechanisms that nudge people in the direction of making better choices, or help prevent making poor choices, without closing off any choices entirely. ${ }^{98}$

In a sense, this article is arguing that fairness in contract can be rooted in a similar notion of "libertarian paternalism." That is, it looks to make contracts voidable by a party when that party was unable to rationally consider her own interests with respect to the terms of the agreement, subject to the major caveat, discussed in more detail later, that requires the other party to have actual or constructive knowledge of such a deficiency.

It should be noted that large institutions, which normally take more time to enter agreements and which have more checks and balances on individual decision making, are also less likely to behave irrationally. ${ }^{99}$ This is not to say that large and sophisticated institutions are incapable of entering contracts with irrational terms, ${ }^{100}$ although it appears less likely that they will do so. It would likely be harder, therefore, for a large firm to argue

Ibid at 249-50.

Thaler \& Sunstein, supra note 67 at 103.

Kahneman, supra note 89 at 300.

See generally Hayden \& Ellis, supra note 65.

Ibid at 639. The origin of the term "bounded rationality" can be attributed to Herbert A Simon, Models of Man: Social and Rational; Mathematical Essays on Rational Human Behavior in a Social Setting (New York: John Wiley \& Sons, 1957).

Kahneman, supra note 89 at 417.

See e.g. 16 CFR $\S 429.1$ (in the US); Consumer Protection Act, 2002, SO 2002, c 30, Sch A, ss 29-36, 41-43.1 (in Ontario, Canada).

Thaler \& Sunstein, supra note 67 at 4

Kahneman, supra note 89 at 417-18.

For an account of institutional blindness with respect to potentially harmful terms in contracts, see Mitu Gulati \& Robert E Scott, The 3 1/2 Minute Transaction: Boilerplate and the Limits of Contract Design (Chicago: University of Chicago Press, 2013). 
that it was not in a position to consider its own interests on the basis of psychological biases, though perhaps not impossible depending on the circumstances.

So far this section has addressed what it means for a decision to be rationally selfinterested in a general utilitarian sense, and how human rationality when making decisions is sometimes questionable. But I have not yet addressed how the normal subjects of fairness doctrines in contract, such as duress, undue influence, or "inequality of bargaining power" might undermine the rationality of a party entering a contract.

Consider the paradigmatic example of extreme duress: the contract made at gunpoint. We might be tempted to say that the party under threat behaved rationally in entering the contract, and was absolutely considering his own interests when he chose to do so. When considered against the alternative of almost certain death, it was rational that the party under threat enter the agreement, and it certainly resulted in a higher expected welfare. What, then, is the purpose of discussing the protection of rational self-interest as the basis of fairness in contract when such an obviously unfair agreement can be considered the result of perfect rational self-interest?

To answer the question, it's necessary to understand that the requirement of rational selfinterest applies with respect to the terms of the agreement. In the case of the contract made at gunpoint, the terms of the contract are likely of little relevance to the threatened party; they could well be anything, and he would agree to them. The threat cannot be considered part of the terms of the agreement itself: such a term is clearly illegal and unenforceable, and is therefore an external pressure. It can hardly be said he rationally considered his interests with respect to the terms of the agreement, even if he was able to consider his interests with respect to the overall situation.

While this is an extreme example, the same considerations can be applied to other doctrines of fairness, and can address the problematic notion of "inequality of bargaining power." While referred to frequently in unconscionability cases such as Macaulay $v$. Schroeder, ${ }^{101}$ the courts have left the precise meaning of the term "inequality of bargaining power" largely underdeveloped, ${ }^{102}$ despite some attempts to explain the concept.

An example of such an attempt is Lloyds Bank Ltd v. Bundy, ${ }^{103}$ in which the England and Wales Court of Appeal considered the circumstances of Bundy, a farmer who had mortgaged his ancestral farm and only asset to cover the debts of his son's company. Naturally, his son's company faced further difficulties, and the bank sought sale of the farm. The case appears on its face to be one of undue influence, and indeed, Bundy was excused from the agreement on that basis by two of the three judges. However, Lord Denning, in similarly excusing Bundy from performance, reviewed five extant categories of fairness that excuse parties from 
performance, including undue influence and undue pressure, and united them into an analysis under the heading of "inequality of bargaining power." In his reasoning, inequality of bargaining power will exist where a party

without independent advice, enters into a contract or transfers property for a consideration which is grossly inadequate, when his bargaining power is grievously impaired by reason of his own needs or desires, or by his own ignorance or infirmity, coupled with undue influences or pressures brought to bear on him by or for the benefit of the other. ${ }^{104}$

While Denning's reasoning is laudable and closely resembles the analysis proffered here, "inequality of bargaining power" is not a particularly useful term to encompass the various elements he subsumes into it. It remains unclear what, precisely, "bargaining power" is, and the inquiry is less interested in inequality than an impairment in the breaching party's ability to consider her own interests. For example, consider a hypothetical case of two parties that enter an agreement with each other, both of whom are being pushed by great external pressure to accept an agreement. Here we have prospectively equal bargaining power, in that both are exhibiting weak bargaining power, but that does not seem a good reason to enforce the agreement.

My goal here is not to find a meaningful definition of "inequality of bargaining power," but rather to suggest that what the courts should, and largely are, engaged in is instead an analysis of whether the individual was in a position to rationally consider her own interests with respect to the terms of the agreement. This analysis looks at whether significant external pressure, lack of knowledge or information, or psychological barriers, such as predictable cognitive biases, were sufficiently present to force the breaching party to accept unfavourable terms (in the sense of being rationally welfare-decreasing). One way of thinking of this question is to ask what were the external, informational, or psychological impediments to walking away from the agreement?

Denning's reasoning in Bundy, which attempts to determine fairness by holistically examining external influences and pressures, adequacy of legal counsel, issues of capacity, and the terms of the agreement itself, effectively does just this, but without acknowledging that it is an inquiry into rationality. Thus, using the analysis outlined in this article, and as demonstrated further in Part V, this analysis can also account for what courts have traditionally called "undue influence" and "inequality of bargaining power."

\section{The Notice Rule: The Requirement of ACtual or Constructive Knowledge of the Non-Breaching Party}

The requirement that the non-breaching party have actual or constructive knowledge of the breaching party's inability to rationally consider her own interests may be troubling. After all, if the welfare-enhancing nature of an agreement arises as a result of both parties 
being able to consider their interests, then why not allow a party that was unable to consider its interests for any reason to escape the agreement, regardless of the knowledge or constructive knowledge of the other party?

This is why it is imperative to consider the operation of contract as promoting welfare in the aggregate at a societal level. If an agreement could be set aside for reasons that are unknowable to one party after formation, contracting parties would have little certainty about whether their contracts could be enforced. Indeed, a presumption of voidability may dominate, especially where sophisticated parties enter agreements with non-sophisticated parties. In this way, the confidence in the institution of contract would likely be heavily damaged, and the costs of self-insurance against reliance upon an agreement would be large.

It would also be a significant economic cost for parties to an agreement to investigate the state of the other party in order to determine whether it is in a position to consider its own interests, and such an investigation may be further harmful to the investigated party. The loss of confidence in the institution of contract, the potential incentives to perform costly investigations, and the harm that might be inflicted by a privacy-breaching investigation into the other party's affairs are likely to exceed any welfare produced (or costs avoided) through the non-enforcement of contract in the cases where a party could not consider its own interests and where this fact was unknowable to the other party. Thus, while perhaps unfortunate, to maintain the institution of contract, fairness may not triumph in all individual cases. However, protection of the institution of contract creates a net utility gain that outstrips the prospective losses to individual parties. ${ }^{105}$

There is another reason to prefer the requirement of actual or constructive knowledge of the non-breaching party, and it demonstrates the value of viewing contract at a societal and aggregative level. Earlier, I stated that an ideal principle would not only provide a remedy for unfair contracts, but would actively prevent the formation of unfair contracts. In order to do so, prospective contracting parties must have a basis on which to avoid such contracts. In this case, the rule would make it clear to a party that law expects them to avoid or remedy a contract where, given the information it has, it is reasonable to believe that the other party could not rationally consider her own interests with respect to the terms of the agreement. This should not impose any additional significant costs on that party, as it is not incumbent upon it to seek out any new information. The economic costs of obtaining the information and avoiding the contract should be trivial. Additionally, where it is suspected that the other party is unable to rationally protect her interests, the situation may be remediable, depending on the circumstances, by, for example, ensuring the other party receives sufficient information to make a rational decision or by ensuring they obtain independent legal or institution of contract remains stable. In other words, what justifies sacrificing the welfare of some for the sake of the whole? Again, I answer that the justification lies in the social contract. We choose a system that promotes greater welfare overall (and is thus more likely to increase our own welfare) even if that system may occasionally seem unfair to us in individual cases. Again, however, if identifiable individuals or groups are repeatedly prejudiced by such a system, additional protections may be warranted. See supra note 49 and accompanying text. 
financial advice. Where it is not remediable, the notice rule may encourage parties to avoid the contract, along with potential costly litigation and harm to the disadvantaged party. This may push banks and other sophisticated firms to simply avoid agreements or remedy them where it appears that the other party is subject to influence or lacks the capacity in any other way to meaningfully consider his own interests in the negotiation and execution of the contract. $^{106}$

It could be argued that some breaching parties will be systemically disadvantaged by the notice rule as their unique circumstances, which might otherwise make an agreement voidable, might not generally be apparent to the other party, and thus they cannot take advantage of this fairness principle. These might include, for example, those with mental illnesses or disabilities that limit their capacity. I would, therefore, create one exception from the rule for special categories of capacity that may not be apparent to the other party, such as for minors and those with mental handicaps, as is well-recognized by the law. ${ }^{107}$ Cases in which these special categories arise are likely to be few enough that the costs of selfinsurance against reliance on an agreement later voided by a person of limited capacity, or the costs of inquiry into capacity, will be limited, while the harms associated with enforcing agreements against those of limited capacity are likely to be great.

While it is possible that there are other cases of systemic disadvantage under the notice rule beyond these already well-established issues of capacity, such individuals or groups, it seems, would have to be specially contemplated by contract law on the basis of their systemic lack of ability to effectively contract. The law indeed does this in some cases through consumer protection legislation. For example, in Ontario, payday loans are heavily regulated, ${ }^{108}$ including by setting the maximum amount that can be charged by a payday lender. ${ }^{109}$ This follows from the fact that borrowers of payday loans are often in urgent need of financial help, and may agree to highly unreasonable terms. ${ }^{110}$

I reiterate that the notice rule does not apply in the rare scenarios where both parties to an agreement were unable to rationally consider their interests. ${ }^{111}$ In such a case, the economic rationale for the notice rule is significantly reduced. First, such agreements even more clearly undermine the basis for contractual enforcement discussed in Part III, providing a stronger case for a straightforward rule of non-enforcement. Second, it is much less likely that unfair agreements can be ex ante avoided or remedied by either party if both parties are unable to properly consider their interests, as they are less likely to perceive any inequity due to their own deficiencies. Third, it hardly undermines certainty in the institution of contract from the

For example, in cases in which a spouse provides security for the debts of the other spouse. See e.g. Royal Bank of Scotland plc v Etridge (No 2), [2001] UKHL 41, [2002] 2 AC 773 [Etridge] (discussed below). For a review of a number of cases of this sort, focusing on the UK but including international cases, see G Gretton, "Sexually Transmitted Debt" [1999] J South African L 419.

See e.g. Sale of Goods Act, RSO 1990, c S.1, s 3 (in Ontario); Sale of Goods Act, RSA 2000, c S-2, s 4 (in Alberta).

Payday Loans Act, 2008, SO 2008, c 9.

General, O Reg 98/09, s 23.

Pearl Chin, "Payday Loans: The Case for Federal Legislation" [2004] U Ill L Rev 723 at 727-28.

For example, in cases of common mistake, discussed in Part V, below. 
perspective of any one party to have a rule of non-enforcement in cases where it is guaranteed that that party is unable to consider its own interests; indeed, it seems rational that any party would prefer a general rule of non-enforcement in such cases.

In this way, any one party has certainty that its agreements will only be voidable where either (a) it has notice of the other party's inability to rationally consider its interests, or (b) where it is itself a party unable to rationally consider its own interests.

\section{Practicality}

One necessary issue to address is whether the analysis so far disclosed is practical for a court to implement in individual cases. While this will be demonstrated when addressing the individual doctrines of fairness, a few preliminary matters are worth addressing.

The first of these is the question of how a court is to know whether a party was able to rationally protect her self-interest in a given case. The court cannot look into the mind of the party and determine whether the terms could have seemed rationally utility-increasing at the time of contractual formation to that party relative to that party's subjective preferences. However, courts need not do this in practice. Rather, the analysis of the court should be directed towards the circumstances of the party at the time of contract formation to see if it seems likely, on a balance of probabilities, that external factors or predictable psychological biases (such as in the case of high-pressure sales) might make a party unable to rationally consider the terms of the agreement and weigh the costs against the gains. Thus, the focus need not look deeply at the mind of the litigant, but rather at their factual circumstances. Where courts accept evidence that a given litigant was especially susceptible to external factors or biases, that argument would be tempered by the notice requirement that the other party had actual or constructive knowledge of such deficiencies.

Another question is how a court is to weigh the actual terms of the agreement from which the breaching party seeks to escape. The analysis presented here would suggest that the terms of the agreement cannot, alone, be determinative of the question of fairness. Again, it is not the role of the court, nor is it reasonably possible, for a court to inquire into the subjective valuations of the parties as of the time of contract formation. That said, however, what appear to be extremely one-sided terms can certainly be relevant to understanding the circumstances around which the agreement was made. Where a transaction appears to be so one-sided such that it "called for an explanation,"112 it may well factor into the question of whether it was more likely than not that certain circumstances did render the breaching party unable to rationally consider her own interests. ${ }^{113}$ However, the nature of those circumstances must also be before the court; an apparently unequal transaction, without further evidence of the circumstances giving rise to that transaction, cannot be enough. This requirement, as it happens, mirrors the approach of nineteenth century English jurists, who would not inquire 
into the adequacy of consideration, except when combined with other things that might suggest fraud or undue influence. ${ }^{114}$

An additional point of contention may be that this analysis gives too much discretion to the courts and that it is unpredictable, in practice, from the perspective of contracting parties. This is certainly true, but I believe the analysis offered here is no more discretionary than any fairness analysis conducted under existing doctrines of fairness, and is indeed, due to the notice rule, likely more predictable to the parties. While far from providing absolute certainty, it does offer a general standard against which a contracting party can adjudge the opposite party and avoid contracts where possible, and it also offers additional guidance both to the courts and to litigants about the questions that will be asked and the facts that need to be proved.

Finally, the notice rule itself requires additional work by the courts. It may be difficult, in certain circumstances, to determine whether the defendant knew or ought to have known about the plaintiff's inability to rationally consider her own interests. However, such an inquiry is far from impossible. Indeed, courts have already engaged in just such an analysis in the case of unilateral mistake, in which courts have allowed a breaching party to escape a contract where it was mistaken as to a term or underlying fact, and the other party knew, or ought to have known, about their mistake. ${ }^{115}$ Given that courts have endeavoured in the past to investigate what was known, or ought to have been known, by the parties to an agreement at a certain time, it does not seem likely that the notice rule would overly burden them for the purposes of the present analysis.

\section{APPlying The UNified APPROACH TO EXISTING DOCTRINES OF FAIRNESS}

I now turn to a discussion of how several of the existing doctrines of fairness in contract can be explained and unified under this analysis. For present purposes, I will look at the doctrines of undue influence, duress, mistake, and unconscionability, as well as the deficiencies of standard form contracts.

\section{A. UNDUE INFLUENCE}

Undue influence is typically divided into two fundamental classes. The first is that of actual undue influence, in which the defendant has in some way directly placed pressure on the plaintiff to the agreement. The second class is that of presumed undue influence, in which the plaintiff can show that he or she was in a relationship of trust with the defendant and that

114 Waddams, Principle and Policy, supra note 2 at 100.

115 See e.g. Alampi v Swartz, [1964] 1 OR 488 (CA) (in which it was held that if a party knew or could be taken to know of a unilateral mistake by the other party, it is tantamount to fraud); 421990 Alberta Ltd $v$ Royal Trust Corp of Canada, [1995] 9 WWR 66 (ABQB) (in which the acceptance of a settlement offer which the offeree knew contained a mistake concerning the monetary claim invalidated the settlement agreement). See also Anthony T Kronman, "Mistake, Disclosure, Information, and the Law of Contracts" (1978) 7 J Leg Stud 1 at 6-7 [Kronman, "Mistake"]. 
the transaction calls for an explanation. ${ }^{116}$ In this second class, the defendant must then show that the plaintiff entered the agreement with fully informed consent, such as by showing that the plaintiff had obtained independent legal advice. ${ }^{117}$

As Chen-Wishart notes, the current debate about undue influence largely concerns whether the doctrine of undue influence is plaintiff-focused or defendant-focused. ${ }^{118}$ That is, is undue influence a question of the quality of the plaintiff's consent or a matter of wrongdoing by the defendant? As discussed earlier in Part II, neither approach offers a sufficient explanation for the doctrine of undue influence.

The view articulated in this article can, in a sense, be said to be plaintiff-focused, despite looking to the defendant for actual or constructive knowledge of the plaintiff's inability to rationally protect his own interests. This is because this view is first interested in knowing whether the plaintiff was in a position, given the circumstances, to rationally consider her own interests with respect to the terms of the agreement. This should not, however, be treated as an analysis into the quality or defectiveness of consent. Consent, in its ordinary sense, may be given freely, as it was in Allcard, ${ }^{119}$ yet the plaintiff's ability to consider his or her own interests may be compromised. While it is certainly possible to stretch the meaning of "consent" to include the analysis proposed in this article, doing so is unhelpful as it moves the meaning of the term too far from its common understanding.

Instead, what must be addressed is the nature of the transaction, the relationship between the parties, and any other circumstances that may have impaired the plaintiff's ability to act in a self-interested and rational manner. Strict categorization of relationships or transactions is largely unhelpful here, although the nature of those relationships remains relevant. Indeed, the court should consider any relevant facts together simply as evidence of whether the plaintiff was able to enter a self-interested agreement without being unduly constrained by outside pressures or cognitive biases. As discussed earlier, the terms of the transaction should also not be ignored entirely in establishing this evidence, and indeed the courts have not done so. ${ }^{120} \mathrm{~A}$ particularly one-sided transaction may well indicate one party's inability at the time of formation to rationally consider her interests, even if, as I argue, such evidence cannot be determinative without a further explanation as to why the plaintiff was not in a position to consider her interests.

The second stage of the analysis would turn to a question of whether the defendant knew, or should have known, that the plaintiff was not in a position to consider her own interests.

Chen-Wishart, "Undue Influence," supra note 23 at 233-34.

Ibid.

Ibid at 236.

Allcard concerned a woman, Allcard, who joined a Christian religious order led by the lady superior Miss Skinner. Upon joining, she was required to abide by vows of poverty and obedience. Shortly after joining the order, she made a significant gift of her assets to the order. She later left the order, and claimed to recover her assets. The Court found that there was undue influence despite the lack of wrongdoing on the part of the order or Miss Skinner. However, recovery was denied due to the passage of time between her leaving the order and bringing the claim. See Allcard, supra note 24.

See e.g. ibid; Etridge, supra note 106. 
Here, again, the question is fact-specific. As previously discussed, the court should not require that the defendant have made significant inquiry into the status of the plaintiff. Rather, the court should ask whether, given the nature of the transaction, the relationship between the parties, and any other knowledge about the plaintiff imputable to the defendant based upon their negotiations and relationships, the defendant should have known that she could not have rationally considered her interests.

This analysis can readily be applied to Allcard. ${ }^{121}$ In that case, while the plaintiff freely consented to make the donation to her new convent, the Court saw that, despite there being no wrongdoing on the part of the defendants, she was under the "spiritual influence" 122 of her new religious order. ${ }^{123}$ The Court effectively found that this spiritual influence placed her in a circumstance in which she could not properly weigh and value her interests. Additionally, the extreme nature of the gift, which appeared unusual in the sense of giving up much of her wealth without receiving something of a similar monetary value, called for an explanation and added weight to the conclusion that the plaintiff could not rationally make that judgment. ${ }^{124}$ Of course, the Court noted that this apparent inequality in exchange could not ground the decision alone, but could only do so in combination with the influence exerted. ${ }^{125}$

The second part of the present analysis was also met. Constructive knowledge of the spiritual influence affecting the plaintiff's decision could clearly be imputed to the defendant on the basis that the gift was a result of the vows imposed by the defendant's own order. ${ }^{126}$

Naturally, the finding does raise some problematic questions. After all, Allcard concerns a woman who chose to give up her wealth based upon her spiritual convictions. If the defendants did nothing wrong other than influence her spiritually, then the holding raises the possibility that spirituality in itself is an influence that may lessen one's rational faculties. If a Catholic, for example, were to make a large gift to his parish that he later regrets, would it be unfair for the parish to seek to keep it? This seems like a truly unpleasant question to have to answer, especially should that religious person claim in court that he was blinded by his faith. However, even if indirectly, this is effectively the question that the Court in Allcard did answer. Fortunately, however, this article is not concerned with enumerating specific circumstances in which rationality is vitiated. Our answers to questions about such things as whether spirituality or religious beliefs can vitiate rationality will likely change with societal views and our understanding of human psychology. The argument here proposes simply the questions that should be asked in cases of fairness, not the proper answers to all such questions. 
The case of Etridge is also easily amenable to this analysis. That case, in which eight separate appeals were joined, concerned mortgages used to secure business loans from a bank. The loans were taken out by husbands who had their wives guarantee the agreements. When the businesses failed and the bank claimed repossession of the mortgaged property as security on the loan, the wives claimed that their equity in the home should remain with them as they were under undue influence in signing the agreement, and had gained nothing from the loan. ${ }^{127}$ The Court held that a bank is on notice when such a transaction is entered into that the wives must not be under the influence of the husbands and that the bank must ensure that the wives have obtained independent legal advice. ${ }^{128}$

This outcome is readily explicable upon the grounds I have already discussed. Here, a transaction was found to be questionable on the basis that the wives were in a relationship of trust with their husbands and the loans were not for the wives' purposes. Because of this last point, the Court found that the agreement should have raised red flags for the bank. ${ }^{129}$ The Court, it could be said, in finding undue influence in some of the appeals, found that the wives were not in a position to rationally protect their own interests with respect to the terms of the agreement. The outside influence of the marriage relationship, and the interest in protecting that relationship, overwhelmed any ability to rationally consider those terms. The Court also engaged in the second part of the analysis, finding that the bank had constructive knowledge of this deficiency and should have ensured that the wives had obtained independent legal advice before the agreements could be found to be enforceable. ${ }^{130}$

As we have seen, an application of the principle of protecting rational self-interest where the fairness of a contract is questionable can explain the results of two highly influential undue influence cases (Etridge and Allcard), and identify the questions at the heart of the court's analysis.

In the Canadian context, we can look to a case in which a transaction was not set aside for undue influence. The case of Geffen v. Goodman Estate ${ }^{131}$ concerned whether a trust established by a deceased woman, Tzina Goodman, was voidable for undue influence. During her life, Tzina had a history of severe mental illness, and was diagnosed with bipolar affective disorder and immature personality. She inherited her house outright from her mother, but her siblings were concerned that she would not be responsible with the property and would fail to maintain the assets she needed to support herself, making them financially responsible for her upkeep. To this end, the family retained a lawyer, and after some discussion, it was agreed that Tzina would put the property in a trust which would maintain the property for her benefit for life, and would be divided up between all of her mother's grandchildren upon Tzina's death. Tzina's will, however, attempted to leave the trust property to her children alone. After much litigation, the Supreme Court of Canada was

Etridge, supra note 106 at paras 5-6.

Ibid at paras 79-80.

Ibid at para 44 .

Ibid.

[1991] 2 SCR 353. 
called upon to determine whether the trust agreement was made under the undue influence of Tzina's brothers.

The Court, in holding that undue influence had not been proven, attempted to fashion a flexible test for undue influence from first principles. ${ }^{132}$ It rejected any strict categorization of relationships that might give rise to a presumption of undue influence, and rejected the notion that undue influence concerns either just the process leading to the agreement, or just the unfair result of the agreement. ${ }^{133}$ The Court also rejected the idea that the plaintiff must demonstrate a "manifest disadvantage" created by the agreement in order to find a presumption of undue influence. ${ }^{134}$ Instead, the Court framed the issue as an inquiry into whether one has dominated the will of another, which could arise in many different types of relationships. On this basis, the Court found that the relationship between the brothers and Tzina was sufficiently close, especially during Tzina's grief following her mother's death, to create the kind of relationship that could give rise to undue influence. However, the Court held, on the facts established at trial, that that presumption was rebutted. The evidence showed that Tzina was not relying on her brothers in establishing the trust, that she had little contact with them at the relevant time, and that the brothers only sought to advance her interests in any event. Therefore, there was no undue influence. ${ }^{135}$

Again, we have a court that appears to be attempting to protect the rational self-interest of the parties, but also enforce agreements where that interest has been sufficiently protected. While Tzina, due to her mental issues, her grief following her mother's death, and her relationship with her brothers, may have been in a position to have her will dominated and thus not rationally consider her own interests with respect to the terms of the agreement, the evidentiary record disclosed no reason for believing that is what actually happened. Indeed, the trust was established in her best interests, and there was little reason to assume that she was incapable of understanding that and rationally creating the trust at the relevant time. The evidence also indicated that her brothers were not the reason she agreed to enter the trust. The manner in which the majority of the Court rejected any analysis that focused solely upon the terms of the agreement, and instead directed its focus towards the external forces that may have dominated Tzina's will, is a perfect demonstration of the analysis presented in this article. ${ }^{136}$ Put another way, the Court essentially inquired whether Tzina was in a position to rationally protect her own interests, and answered in the affirmative.

\footnotetext{
Ibid at 374 , Wilson $\mathrm{J}$.

Ibid at 376 .

Ibid at 377 .

Ibid at 378-90.

It is noteworthy that the judgment of Justice Wilson (joined by Justice Cory) does state that manifest disadvantage may have to be shown in cases of commercial transactions: ibid at 377 . However, this is obiter, and indeed, the concurring judgment of Justices La Forest and McLachlin rejects this claim, leading to a split on the issue as Justice Sopinka concurred on entirely different grounds. Thus, the holding of the Supreme Court establishes that, at least in non-commercial cases, the focus is solely upon whether the plaintiff's will had been dominated.
} 


\section{B. DURESS}

The case of duress is little different. For a paradigmatic example of duress we can look to the United Kingdom's case of Barton ${ }^{137}$ in which Barton entered an agreement with Armstrong to, among other things, purchase his shares of a corporation in which both had been involved. When the company faced financial difficulties, partially as a result of the terms of the agreement, Barton later claimed that the agreement was made under duress, and sought to have it set aside. Specifically, he claimed that Armstrong had repeatedly threatened his life, and even hired someone to kill him, unless he signed the agreement. ${ }^{138}$ The Privy Council accepted some of these allegations, but questioned whether Barton would have signed the agreement even in their absence. In the end, the majority held that while the threats were not the only, or even primary, reason for signing the agreement, they were nonetheless $a$ reason, and this was sufficient for a finding of duress. ${ }^{139}$

The application of the analysis presented in this article to this case is relatively straightforward: assuming there was indeed some form of duress, and that it indeed contributed to the decision to enter the agreement, it is quite clear that Barton was not in a situation under which he could rationally consider his own interests with respect to the terms of the agreement. Should the Court have found that the threats in no way impacted the decision, then this would, as the Court noted, be different, as presumably Barton would have demonstrated the ability to rationally consider his interests even in the face of such exterior forces. But where the duress contributed to the decision, it is impossible to separate its contribution from the contribution of other factors, and thus, we might expect that at least some of the terms may have been different had the duress not existed. To suggest that the agreement would have been made anyway is really to suggest that the duress did not impact the rationality of Barton. Thus, when the dissent found against him for the reason that the facts suggested he truly made the agreement for commercial purposes and not due to the duress, they were essentially arguing that he was acting rationally and in his own interest in making the agreement. The second part of the analysis (the aforementioned "notice rule") is trivial. Naturally, knowledge of the threats on Barton's life is imputable to Armstrong, as he made the threats, allegedly to push forward the agreement. In this way, both the majority and the dissent can be explained by application of this principle.

We can apply the same considerations to economic duress, which occurs where the pressure being placed upon the plaintiff arises due to financial or economic concerns rather than a physical threat or a threat to property. ${ }^{140}$ Economic duress is not truly different from duress, being "an expansion in kind but not class of practices that the law already recognizes as unacceptable." 141 The Canadian approach to economic duress follows from the UK

Barton, supra note 14.

Ibid.

Ibid.

Stott $v$ Merit Investment Corp (1988), 63 OR (2d) 545 (CA) [Stott]. Ibid at para 48 . 
approach ${ }^{142}$ presented in Pao On v. Lau Yiu Long, ${ }^{143}$ which itself followed from the principles developed in Barton for traditional duress. ${ }^{144}$

In Canada, as in the UK, to make out economic duress, there "must be a pressure which the law does not regard as legitimate and it must be applied to such a degree as to amount to "a coercion of the will." 145 The question of whether there has been a coercion of the will has been addressed by looking at four contextual factors: whether the plaintiff protested against the transaction, whether there was a reasonable alternative to making the agreement, whether she was independently advised, and whether she took steps to avoid the contract after it had been made. ${ }^{146}$ However, these factors are only evidence of whether there has been a coercion of the will, and, understandably, the question of a reasonable alternative to entering the agreement appears most determinative. ${ }^{147}$

Consider the Ontario case of Hill v. Forbes, ${ }^{148}$ in which an agreement was entered for the purchase of a home and for it to be moved, by heavy equipment, to a particular location. The price was paid in advance, but the agreement allowed the purchaser to reject the home under certain circumstances, which she did. The purchaser then demanded her money back, and refused to allow the seller to remove his moving equipment from her property until he entered another agreement setting out repayment of the purchase price. He agreed to this second contract, but later claimed he did so only under duress because he needed his equipment for other projects. ${ }^{149}$ The Court rejected the seller's claim of economic duress on the grounds that he clearly had other options available to him. Primarily, he failed to bring timely legal proceedings to recover his equipment, which was an option clearly available to him. He also waited five days before signing the second agreement (suggesting the matter was not conducted with great urgency), failed to seek out any advice during that time, and did not seek to escape the second agreement until more than a year after it was signed. ${ }^{150}$ The Court ultimately stated that there was "no basis for saying any pressure the appellant may have felt was of such a nature as to deprive him of 'his freedom of exercising his will.",151

The Court in addressing whether the economic duress was sufficient to deprive the seller of "his freedom of exercising his will" is almost directly making an inquiry into whether he was capable of rationally considering his own interests with respect to the terms of the agreement in the circumstances. In this case, the evidence was insufficient to establish that any external pressures, or other factors, prevented the seller from doing so. That the case turns on the question of whether there were reasonable alternatives available to him mirrors

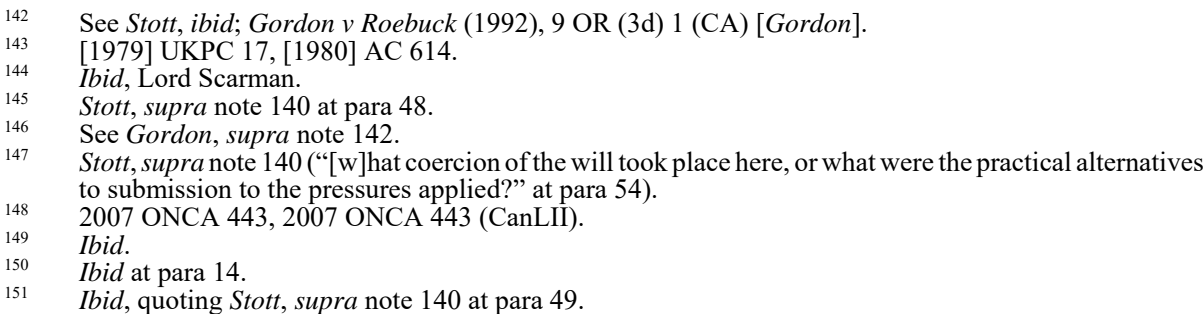


the analysis established in Part IV, above, which similarly asks what the external, informational, or cognitive impediments were to walking away from the agreement. Thus, economic duress, like more traditional forms of duress, can quite clearly be explained as an inquiry into whether the plaintiff could rationally consider his own interests with respect to the terms of the agreement. Indeed, the inquiry into whether the pressure applied was sufficient to deprive him of "his freedom of exercising his will" appears to be precisely this question in slightly different words.

\section{UNCONSCIONABILITY}

Unconscionability is a somewhat protean concept with little agreement about its fundamental terms. Indeed, unconscionability is a doctrine burdened by many concepts, two of which are important for present purposes. The first of these is the debated distinction between "procedural" and "substantive" unconscionability. ${ }^{152}$ Procedural unconscionability typically refers to a defect in the process of contracting, while substantive unconscionability refers to an imbalance in the terms of the contract itself. ${ }^{153}$ More specifically, procedural unconscionability "arises out of defects in the process by which the contract was formed, and 'can include a variety of inadequacies, such as age, literacy, lack of sophistication, hidden or unduly complex contract terms, bargaining tactics, and the particular setting existing during the contract formation process," "154 while substantive unconscionability "suggests the exchange of obligations so one-sided as to shock the court's conscience."155

The second concept is the common framing of unconscionability as "inequality of bargaining power" ${ }^{156}$ between the two parties to a transaction. As Lord Diplock put it in Macaulay:

what your Lordships have in fact been doing has been to assess the relative bargaining power of the publisher and the song writer at the time the contract was made and to decide whether the publisher had used his superior bargaining power to exact from the song writer promises that were unfairly onerous to him. ${ }^{157}$

The two concepts are related, as procedural unconscionability is often put in terms of unequal bargaining power. ${ }^{158}$ While some law and economics scholars, such as Michael Trebilcock, have suggested that only the procedural unfairness, as an imbalance of bargaining power, is relevant to an assessment of unconscionability, ${ }^{159}$ this article argues that both are relevant, even if what might be termed "procedural unconscionability" is the more determinative of the two insofar as it more directly establishes the circumstances under

These terms were coined in Arthur Allen Leff, "Unconscionability and the Code - The Emperor's New Clause" (1967) 115:4 U Pa L Rev 485 at 487. See also Waddams, "Unconscionable Contracts," supra note 2 at $3-4$.

$153 \quad$ Leff, ibid at 487

154 Rodriguez v Raymours Furniture Co, 93 A (3d) 760 at 767 (NJ Sup Ct App Div 2014).

155 Ibid.

156 Trebilcock, "Economic Approach," supra note 18 at 385.

157 Macaulay, supra note 101 at 1315.

158 Trebilcock, supra note 18 at 391-92.

159 Specifically, Trebilcock is interested in the structural and informational health of the market in which the agreement operates. See ibid. 
which the agreement was entered. However, the substantive elements of the agreement provide important information and evidence as to the circumstances in effect at the time of contract formation. Indeed, Trebilcock, in his discussion of the Macaulay case, appears to put very little emphasis on the long discussion of the terms of the agreement engaged in by the court, ${ }^{160}$ without which it seems unlikely the court would have reached the same conclusion. In this way, "procedural" and "substantive" unconscionability are better perceived as two sides of the same coin, rather than being meaningfully separate.

Additionally, as discussed earlier, "inequality of bargaining power" is a very unclear concept that can mean multiple different things. In the context of procedural inequality, it appears to mean a combination of three elements: (a) the circumstances of the contractual formation created a deficiency in the breaching party's ability to rationally consider its interests; (b) this deficiency was created or leveraged against them by the party seeking enforcement; and (c) the party seeking enforcement thus had at least constructive knowledge of the breaching party's lack of ability to rationally consider her own interests.

We can see how these elements interact by reviewing the facts of the paradigmatic American unconscionability case of Williams v. Walker-Thomas Furniture. ${ }^{161}$ In that case, Walker-Thomas, a furniture store, sold household items to a number of customers between 1957 and 1962 for which payment was to be made in monthly installments. The contract governing the sales stipulated that title to the items would remain with Walker-Thomas until the full cost of the items was paid. Should the purchasers default in payment of any monthly installment, Walker-Thomas was entitled to repossess the item. ${ }^{162}$ Additionally, the contract contained a clause that ensured that, if a purchaser bought more than one item, title to all items would remain with Walker-Thomas until all items were fully paid for, even the items that were not purchased as part of the same transaction. Inevitably, a number of purchasers defaulted, and Walker-Thomas sought to repossess all of their purchased items, which in some cases included items bought over the course of multiple years. ${ }^{163}$

In deciding to remand the decision to a lower court for a full determination on the facts, the US Appeals Court for the District of Columbia stated that unconscionability "has generally been recognized to include an absence of meaningful choice on the part of one of the parties together with contract terms which are unreasonably favorable to the other party." "164 In this way, the Court combined (or rejected the dichotomy between) the notions of procedural and substantive unconscionability, noting as well that choice could be vitiated by "gross inequality of bargaining power," or a lack of understanding or opportunity to review the terms. ${ }^{165}$ While it did not apply these tests to the facts in the case (as it was

Macaulay, supra note 101 at $1310-15$.

350 F (2d) 445 (DC Cir 1965).

Ibid at para 11 .

Ibid at paras 13-16.

Ibid at para 26.

Ibid. 
remanded to a lower court), it seems clear that the Court felt that this case might well fulfil those criteria.

The many considerations the Court looked at fit well within the framework offered in this article. Indeed, like undue influence, unconscionability can readily be explained as a simple question of ensuring that the parties to an agreement were in a position to rationally consider their own interests with respect to the terms of the agreement. The analysis offered here, like the Court, rejects a clear dichotomy between procedural and substantive unconscionability in favour of an inquiry into the circumstances of the transaction, for which the terms may well be evidence.

In Walker-Thomas, the terms of the agreement were incredibly one-sided, yet a large number of individuals signed the agreement. This, in itself, can be seen as evidence that the contract was not clearly presented or explained to them, preventing them from rationally considering their own interests with respect to the terms. The fact that the contract was a standard form contract, and that its terms were somewhat arcane, ${ }^{166}$ also suggests a lack of opportunity for review or negotiation, limiting the possibility that the purchasers had the time or ability to consider their interests.

In the same way, the analysis also merges with the notion of "inequality of bargaining power." Here, the complainants were purchasers who signed a standard form agreement with difficult legal language. They likely lacked both the opportunity at the time of purchase to fully read the agreement and the knowledge, had they read the agreement, to understand it. We might say that this resulted in an inequality of bargaining power by virtue of an inequality of knowledge and understanding. However, in reality, the only relevant consideration is the deficiency it created in the ability of the purchaser to properly weight the terms of the transaction in their own interests. The notion of the inequality of bargaining power also seems to imply, as here, that the non-breaching party used that deficiency to obtain favourable terms. Indeed, the District of Columbia Court of Appeals referred to the store's behaviour as "sharp practice and irresponsible business dealings," 167 strongly indicating its opinion that the store was fully cognizant of its advantage-taking. Based upon this, the notice rule discussed earlier is also clearly met.

Thus, the inquiry into the ability of the breaching party to rationally consider her own interests combines and simplifies both procedural and substantive unconscionability, while also subsuming the complicated and uncertain notion of inequality of bargaining power. Each of the factors taken into account in these concepts remains largely relevant, but they are simplified by directing them towards a single question rather than towards multiple ambiguous steps in a test for unconscionability. 
In the Canadian context, the notions of inequality of bargaining power, procedural unfairness, and substantive unfairness have similarly been merged. In Harry $v$ Kreutziger, ${ }^{168}$ it was said that

[w]here a claim is made that a bargain is unconscionable, it must be shown for success that there was inequality in the position of the parties due to the ignorance, need or distress of the weaker, which would leave him in the power of the stronger, coupled with proof of substantial unfairness in the bargain. ${ }^{169}$

The facts of that case also illustrate the analysis presented here. The plaintiff was an Indigenous man with a grade 5 education and little business experience. He sold his fishing boat, along with the associated fishing licence, at significant undervalue to the defendant, apparently unaware of the value of his fishing licence especially. There was ample evidence that the defendant, on the other hand, was aware of the licence's value. The defendant also told the plaintiff that he, as an "Indian," would have no trouble obtaining a new licence, which on the evidence was a critical factor in the plaintiff agreeing to the sale after much deliberation. This turned out to be false. ${ }^{170}$

On appeal, the British Columbia Court of Appeal applied the above-quoted test, and easily found that the transaction was unconscionable due to the plaintiff's lack of education and business acumen, the clearly undervalued purchase price, the defendant's aggressive approach, and the false representations that the plaintiff could maintain his licence (or easily get a new one). ${ }^{171}$ The Court concluded that the plaintiff had thus been "overborne" by the defendant. ${ }^{172}$

As in Walker-Thomas, the Court here takes a more holistic view of unconscionability, combining notions of procedural and substantive unconscionability, as well as inequality of bargaining power. We can again reframe this holistic view as an inquiry into whether the plaintiff could rationally consider his own interests with respect to the terms of the agreement. The facts found in the case strongly suggest he could not. First, his diminished education and experience appears to place him in a vulnerable position. Of course, that itself is not enough, but the terms of the agreement are also clearly one-sided, and the evidence suggested the plaintiff was not aware of the value of his licence. Further, he was misled into believing that he could easily obtain a new licence. These last factors, taken together, are determinative: they allow us to reach the conclusion that, due to a lack of knowledge about the nature of the thing being sold and misrepresentations being made about it, he could not possibly have rationally considered his interests with respect to the terms of the agreement. One cannot consider one's interest with respect to the terms of the agreement if there is a fundamental misunderstanding of the value of those terms and one's position relative to them. While it is quite possible that he could have walked away from the agreement, the 
combination of his lack of knowledge and the misinformation fed to him made it seem like a good deal, when it was, in fact, clearly not. Thus, we can easily see that there was an informational impediment to him walking away. In this way, the first prong of the approach articulated in this article is met.

The second prong, the notice requirement, is also easily met: the defendant was aware that the defendant undervalued his licence, which was the very reason he aggressively sought to purchase it. ${ }^{173}$ The Court further stated that the plaintiff "was assured falsely or recklessly by the [defendant] that he would have no difficulty getting another licence." ${ }^{174}$ Thus, the defendant either knew or should have known that the plaintiff was acting under false information, and was thus unable to rationally consider his interests with respect to the terms of the agreement. That the Court makes especial note of the superior knowledge and wilful advantage-taking by the defendant suggests that it may be tacitly engaging in a similar analysis to the notice requirement presented here.

\section{MISTAKE}

Mistake comes in three basic flavours: common, unilateral, and mutual mistake. ${ }^{175}$ Common mistake refers to a situation in which both parties to an agreement are mistaken as to the same fact or set of facts that are relevant to the terms, value, or performance of an agreement. Unilateral mistake, unsurprisingly, refers to a situation in which only one of the parties is mistaken with regard to such facts. Finally, mutual mistake, or mutual misunderstanding, refers to situations in which the parties misunderstand each other and thereby enter a contract each believing that the terms refer to something different than what the other party intends.

It might be argued that mistake is not a doctrine of fairness, but that it instead fits more comfortably within doctrines of contractual formation in the sense there can be no meeting of the minds with respect to the terms of the agreement if one or both parties are fundamentally mistaken as to the material facts on which the agreement is based. However, such an argument could also be levied at unconscionability where the unfairness arises due to knowledge asymmetry, or in cases of standard form contracts, where one party has no real knowledge of the terms of the agreement. Thus, as the doctrine of mistake allows one party to escape contractual enforcement on the basis that the agreement itself is deficient, it too may well be considered a form of contractual fairness. As I hope to show, it fits the category quite well.

We can consider these types of mistake through a relatively simple hypothetical: Anne is a homeowner who decides to have a garage sale to clear out various odd and ends from her

Ibid at paras $15-17$.

Ibid at para 15 .

HG Beale et al, eds, Chitty on Contracts, 31st ed, vol 1 (London: Sweet \& Maxwell, 2012) at para 5-005. 
home. Bob comes to her garage sale and is interested in a large vase on display that appears to be from China's Ming Dynasty.

Let us first assume that both Anne and Bob believe the vase to be a fake (a reproduction), something which Anne openly discloses. Bob is interested in the vase nonetheless, and they agree on a price reflecting their perceptions of it. Bob will need to come back with a vehicle large enough to transport it, so the two of them enter a written agreement setting out the price. While Bob is out obtaining a vehicle, an expert on Ming ceramics arrives at Anne's sale, and is stunned to see a real Ming vase worth considerably more than the price at which Anne had agreed to sell it. Honest as he is, he informs Anne of the vase's true value. Naturally, when Bob returns with his vehicle, Anne tells him that she is breaching the agreement, as the vase is worth far more than she originally thought. Litigation ensues. ${ }^{176}$

This is a potential case of common mistake. Following the analysis presented here, the first question would be whether the parties were rationally able to consider their own interests with respect to the terms of the agreement. We can infer that they could not. Both parties were quite certain that the vase was a fake, and thus did not have full information on which to weigh their subjective utilities from the agreement. Had the parties realized the risk inherent in the agreement and clearly assigned or divided the risk, or could either be said to have rationally assumed the risk, it would rebut that inference. But given the circumstances under which the agreement was made, that does not appear to have happened. While neither side had notice of the other's mistake, the notice rule in the present analysis does not apply if both parties were unable to rationally consider their own interests. Thus, the agreement should be voidable by Anne.

As it happens, this accords with the result in Sherwood $v$. Walker, which held that if both parties were mistaken as to the nature of a cow being traded, the agreement was voidable. ${ }^{177}$ It additionally accords with the Restatement (Second) of Contracts, which proclaims a contract to be voidable in cases of mutual mistake unless one party could be said to bear the risk. ${ }^{178}$ Similarly, Canadian law generally holds that a contract is void $a b$ initio in cases of common mistake unless one party bears the risk or was otherwise at fault for bringing about the circumstances leading to the mistake. ${ }^{179}$

The issue of bearing the risk demands slightly more discussion. In some cases, it may well be that a party may be mistaken, yet rationally bears the risk of her mistake. This will most

The facts of this hypothetical are similar to the famous case of Sherwood $v$. Walker, which concerned mutual mistake as to whether a purchased cow was capable of bearing children. Both parties, at the time the agreement of sale was made, thought the cow to be barren, and thus the price was much lower than for a fertile cow. However, it was discovered the cow was pregnant prior to delivery. The Supreme Court of Michigan held the agreement was voidable for mutual mistake: Sherwood $v$ Walker, 33 NW 919 (Mich SC 1887).

Ibid.

Restatement (Second) of Contracts, § 152 (1981) [Restatement of Contracts].

See e.g. Miller Paving Ltd v B Gottardo Construction Ltd, 2007 ONCA 422, 86 OR (3d) 161 (in which, after it was agreed between the parties that payment had been received for goods to be supplied, the plaintiff discovered that it had not received payment, but the risk of ensuring that payment had been made was placed expressly on the plaintiff). 
likely be the case where the contractual terms expressly place the risk on one party ${ }_{1}^{180}$ but it may also be implicit based on the circumstances. ${ }^{181}$ For example, was Anne the operator of an antique store, rather than a garage sale, it may be that she rationally bears the risk of the value of any items she sells. After all, it would be her business to know the value of the items in her store, having them appraised where necessary. Unless there was some additional barrier to an appraisal, it is quite possible that Anne's mistake is a risk she could be said to have rationally bore. I note that, depending on the circumstances, such an argument could also apply to the situation of the garage sale, but as access to the necessary information would likely prove a much larger barrier to most individuals that run garage sales, it appears unlikely. Naturally, the precise context of each individual case may alter a court's decision on this issue. ${ }^{182}$

Now let us alter the hypothetical such that Anne knows the vase to be fake, but Bob believes that it is real. Let us assume that Bob makes some comment to Anne indicating that he believes the vase to be real, but Anne says nothing. They enter an agreement at a price well above what would be expected for a reproduction Ming vase. When Bob returns with his vehicle to pick up the vase, the honest antiques expert is present and informs him that it is fake. Bob seeks to escape the agreement.

Here we have a potential case of unilateral mistake. Following our previous analysis, so long as there was no clear assignment or assumption of the risk that the vase was not real, we can say that Bob was not able to rationally consider his interests with respect to the agreement given his misinformation. Additionally, the notice rule now applies, and is satisfied by virtue of Bob's overheard comment and the high price Bob offered to pay to Anne. As Anne knew the vase was indeed fake, she had full knowledge of his mistake. In this case, the contract, it appears, should be set aside. Of course, circumstances may suggest a rational assumption of risk on Bob's part, but for a casual purchaser, such circumstances are unlikely.

As it happens, again we find ourselves in accord with the Restatement (Second) of Contracts, which similarly proclaims a contract to which one party was mistaken to be voidable if either there was notice of the mistake to the other party or if enforcement would be unconscionable, assuming there was no assignment or assumption of the risk of mistake to that party. ${ }^{183}$ We also find ourselves in accord with Canadian case law, which has held that "[w] here a party knows of another's mistake, or should reasonably know of it, she cannot expect that the law will permit her to take advantage of it." ${ }^{\text {184 }}$

\footnotetext{
180 See e.g. ibid.

181 For a judicial discussion of the issue that confirms this point, see Great Peace Shipping Ltd $v$ Tsavliris (International) Ltd, [2002] EWCA Civ 1407, [2003] QB 679 at paras 80-85.

182 See ibid.

183 Restatement of Contracts, supra note 178, § 153 (1981).

$184 \quad$ McCunn Estate v Canadian Imperial Bank of Commerce (2001), 53 OR (3d) 304 (CA) at para 23. See
} also McMaster University v Wilchar Construction Ltd, [1971] 3 OR 801 (Sup Ct (H Ct J)). 
Mutual mistake, or mutual misunderstanding, can be similarly addressed. Let us assume that Anne has two Ming vases, one of which is real (but slightly damaged) and the other one a reproduction. Both Anne and Bob know which one is real and which one is a reproduction, but they fail to specify which one they are referring to when agreeing to the price. Bob believes he is buying the real one, while Anne thinks she is selling the reproduction. The agreed price also represents a midpoint between what one might reasonably pay for a highquality reproduction and a slightly damaged original. When Bob returns with his vehicle to pick up the vase, Anne refuses to give him the original vase. Bob sues.

Here, neither party can be said to have rationally considered his or her interests with respect to the terms of the agreement, since those terms are themselves unclear. While they may have rationally considered their interests with respect to the agreement they thought they were making, there is no objectively true agreement. ${ }^{185}$ It follows that one cannot rationally consider one's interests with respect to the terms of an agreement when those terms are themselves unclear or non-existent. The notice rule is also unnecessary, as both parties were unable to consider their interests. If, however, a court could objectively find that the contract could reasonably bear only one of the two interpretations, then we have a situation more in line with unilateral mistake, and those considerations should apply.

This, unsurprisingly, coincides with Canadian and UK case law. In Canada, a case of mutual mistake will render a contract void so long as the mistake is "fundamental" to the purposes of the contract (and thus is not merely ancillary), and so long as the parties could not be said to have arrived at consensus ad idem (a meeting of the minds) despite the mistake. ${ }^{186}$ Canadian courts mirror UK courts in this respect, which have similarly held that unless only one of the two interpretations provided by the parties is reasonable, the contract will be set aside. ${ }^{187}$

While it seems so far that the principle presented in this article can well explain current doctrines of mistake, there is one other situation worth considering. Let us now assume in the hypothetical that the vase is real, but Anne believes it to be a fake (a good reproduction). Let us assume that Bob visits the garage sale once, makes careful study of the vase, and then proceeds to research it extensively. After his research, he concludes that the vase is in fact real, but approaches Anne to buy it at a price befitting a reproduction. She makes a comment indicating it to be a fake, but Bob says nothing. They reach a deal, and again, before performance, Anne learns the truth and seeks to escape the agreement.

At first glance, this seems to mirror the previous hypothetical as a case of unilateral mistake, but there is a potentially important new element: the investment put into acquiring analysis into the ability of the parties to rationally consider their own interests. But I discuss this to demonstrate that mutual mistake also poses no problem for the theory presented here. 
the information by Bob. Indeed, Kronman has argued that this is a profoundly important difference, as it changes the economic analysis. ${ }^{188}$ Bob has made investments in obtaining socially useful information about the nature of the vase. This information helps the vase get to the person who values it most, and, in this case, the information might also lead to further valuable historical insights. As a policy, it makes sense to incentivize the production of such information by allowing people like Bob to take advantage of the information by entering such transactions without disclosure. In Kronman's view, where there is an informational asymmetry leading to a unilateral mistake, the court should inquire whether the information possessed by the advantaged party was obtained casually or was obtained as the result of a costly and deliberate search. In the former case, the contract should be set aside, but in the latter, it should be enforced. ${ }^{189}$

The analysis presented here, however, makes no such distinctions, and asks only whether one party was unable to rationally consider her interests, and if so, whether the other party had constructive knowledge of such a deficiency. In this hypothetical, this test is met. Yet it appears at odds with Kronman's economic analysis.

While I accept Kronman's view that such information is useful and should be incentivized, I would defend the approach taken in this article for three reasons. First, Kronman overlooks the ex post costs created by such an approach. Under his framework, a court would have to investigate the costs invested in acquiring the information. As Kronman notes, it is a continuum between casually acquired information and information obtained as the result of a costly search, rather than a strict binary. ${ }^{190}$ Where, precisely, the meaningful distinction lies may be difficult for a court to determine, but that is common in jurisprudence, and thus is no rebuttal. What is more important, however, is that the cost of the information search is almost impossible to know for the aggrieved party without litigation. Thus, such an approach almost guarantees that the aggrieved party will sue once it comes to light that they were taken advantage of on the hopes that it turns out that the information was acquired sufficiently casually for the agreement to be set aside. In this sense, from the perspective of the aggrieved party, they are faced with a litigation lottery, the outcome of which turns on information they do not have until at least the discovery phase of the trial. A rule that encourages litigation is one that will only incentivize waste.

The second reason is that in many cases, the information produced would have been discovered regardless of the extra incentive, even where it is the product of a costly search. Consider the case of a mining company prospecting for resources that finds a major mineral deposit on the land of a homeowner. ${ }^{191}$ The mining company put significant resources into its prospecting and does not disclose the findings when purchasing the property from the

\footnotetext{
188 Kronman, “Mistake," supra note 115.

189 Ibid.

Ibid at 14.

Kronman gives the example of a sulphur mining company that purchased mineral rights from landowners at a low price after determining, at significant cost, that their land had a high likelihood of enormous sulphur deposits. This information was not disclosed to the landowners. See ibid at 20.
} 
homeowner. As a consequence, the property is purchased for a price that does not reflect the economic value of the mineral deposits. Despite the low price of the purchase providing some additional incentives to the mining company, this incentive was unnecessary to the production of the information. The mining company would have conducted the search regardless; as a prospecting mining company, it is its business to engage in prospecting. Without new prospects, it has no business. And it seems unlikely that the possibility to obtain land or mineral rights at a cheap price is the only thing keeping the business afloat. Undoubtedly, even if they disclosed the information to the landowners, they still could have reached a mutually advantageous agreement. Obviously, not all cases will involve a corporation whose business it is to find such information, and the incentives may be necessary for the production of information in some cases, such as our vase hypothetical. However, there will undoubtedly be a significant number of cases, in which the information would be produced anyway, to undermine the rationale for Kronman's approach.

Finally, from a distributional perspective, Kronman's approach seems problematic. In many cases, the party with the informational advantage is likely to be the more sophisticated and wealthier party, as it is in the example of the mining company. Since such an approach works strictly to the advantage of the information-searching party, the approach will, from a broad distributional perspective, favour those who already have the resources to engage in directed and costly searches. In this way, Kronman's approach seems likely to only further increase wealth inequality, and systemically injure those without the resources necessary to engage in such searches.

Given these three additional arguments against a rule that requires a court to differentiate between cases of casually-acquired information and information obtained as the result of a deliberate search, I would differ from Kronman and I would suggest, subject to further research, that the rule presented in this article should be preferred. Here, to the extent my approach disagrees with existing cases,${ }^{192}$ my approach would indeed suggest a modification to the common law.

\section{E. STANDARD ForM CONTRACTS}

I turn now to standard form agreements, which have been the subject of much debate. ${ }^{193}$ Much of the concern with these contracts stems from the observation that few people read these agreements, even fewer understand them, ${ }^{194}$ and even if they were understood, there would be no opportunity to negotiate their terms. For better or worse, however, these contracts have been ubiquitous in daily life for some time. ${ }^{195}$

As Kronman would suggest it does: see ibid at $18-27$.

See e.g. supra note 81 .

Radin, supra note 81 ("even if recipients did try to read the clauses, most often they wouldn't understand them" at 24).

See e.g. Slawson, supra note 81 at 529. 
Karl Llewellyn was amongst the first to discuss them in great detail, arguing that standard form contracts form an important part of the modern marketplace, and only those terms that could be considered "unreasonable or indecent," or which undermine the negotiated terms, should not be enforced. ${ }^{196}$ Since that time, a number of other approaches have been offered to standard form contracts, including their presumptive unenforceability, ${ }^{197}$ and even tortious liability on the part of drafters of unreasonable terms. ${ }^{198}$ Economics approaches, meanwhile, have tended to discourage judicial intervention into such agreements. ${ }^{199}$

An application of this article's proposed test is also germane to standard form contracts. Here, again, we must consider the position of the consumer in the circumstances. A consumer can be presumed to be able to rationally consider their interests with respect to the primary terms of their transaction. Indeed, in most cases, these are equivalent to the "dickered terms" ${ }^{200}$ in negotiated contracts, ${ }^{201}$ and pose little difficulty. However, it is to those terms often referred to as "fine print" that we must turn our attention. To what extent can the consumer be said to have rationally considered their interests with respect to fine print clauses such as limitation of liability clauses, arbitration clauses, or intellectual property assignments in agreements facially unrelated to those issues? ${ }^{202}$

The answer, quite simply, is that generally they cannot. There is no reason to suppose, absent evidence that such a "fine print" clause was fully explained, or that independent legal advice was obtained, that consumers are aware of them ${ }^{203}$ or that they would understand them if they were. ${ }^{204}$ One study found that end-user license agreements (EULAs), which are standard form contracts common when purchasing software, were generally as difficult to read as scientific journal articles, ${ }^{205}$ and contained an average of 1938 words. ${ }^{206}$ It cannot be said, then, that consumers are generally capable of protecting or considering their interests in a rational way vis-à-vis these hidden terms. Consumers, by and large, are simply not in a position to judge their best interests or predict their future utility with respect to many of the agreements they sign. We cannot, therefore, be certain that any such agreements are generally welfare-enhancing, and there is thus no reason to generally enforce them.

Drafting parties must also certainly know of the lack of the consumers' understanding and knowledge concerning the terms of the agreement. While based on the length and complexity

Karl N Llewellyn, The Common Law Tradition: Deciding Appeals (Boston: Little, Brown \& Co, 1960) at 370 [Llewellyn, Common Law Tradition].

See generally Rakoff, supra note 81 .

See generally Radin, supra note 81 . Such tortious liability, Radin argues, might be appropriate where the drafters intended to take advantage of weaker parties.

See e.g. Trebilcock, supra note 18; Douglas G Baird, "The Boilerplate Puzzle" (2006) 104 Mich L Rev 933.

Llewellyn, Common Law Tradition, supra note 196 at 370.

Although even this presumption may be false where the contract is for the purchase of necessities, or where there are no reasonable alternatives to entering the agreement.

For examples of these sorts of agreements, see Radin, supra note 81 at 111-19.

Slawson, supra note 81 ("in the usual case, the consumer never even reads the form" at 530).

Radin, supra note 81 ("even if recipients did try to read the clauses, most often they wouldn't understand them" at 24).

Florencia Marotta-Wurgler \& Robert Taylor, "Set in Stone? Change and Innovation in Consumer Standard-Form Contracts" (2013) 88:1 NYUL Rev 240 at 253.

Ibid. 
of these agreements it would stretch credulity to assert that drafters believe these are read and understood by consumers, any business that uses ubiquitous website analytics would easily be able to clearly see that consumers are not reading their agreements online. One study found that considerably less than 1 percent of consumers even bothered to open a EULA before clicking I agree on a number of websites. ${ }^{207}$ Further, while it might be tempting to say that consumers bring any misfortune on themselves by not reading these agreements, ${ }^{208}$ such arguments do not consider the sheer cost in doing so. One study from 2008 estimated that to read every privacy policy an average Internet user encounters in a year of web surfing would take 76 working days, or 25 complete days. ${ }^{209}$ And this only considers privacy policies. If a consumer read every disclosure and agreement the law prospectively held her to, she might well spend much of her waking life reading these agreements. Drafting firms would thus have to be willfully blind not to realize that consumers do not read and cannot understand these agreements. Thus, the notice requirement is clearly met.

On this basis, under the present analysis, standard form contracts, or at least particular terms within standard form contracts, should generally be voidable at the consumer's option. This, of course, excludes the primary terms of the transaction that are clear to both parties without reference to the standard form agreement. In other words, the view presented here would treat the transaction as though the fine print simply did not exist.

While standard form contracts remain generally enforceable in Canada, ${ }^{210}$ the Supreme Court of Canada recently indicated some willingness to hold them to increased scrutiny. The case of Douez v. Facebook, Inc. ${ }^{211}$ concerned the enforceability of a forum selection clause in Facebook's terms of use, which all Facebook members must agree to. The plaintiff, a British Columbia resident, brought an action in the British Columbia courts claiming that Facebook had used her name and likeness in advertisements without her consent, contrary to British Columbia's Privacy Act. ${ }^{212}$ Facebook argued that its forum selection clause mandated that the dispute be resolved in California courts under California law.

The lead judgment of the Court ultimately held that the forum selection clause was unenforceable, although its reasoning was particular to an analysis of forum selection clauses. $^{213}$ However, the lead judgment did recognize that "commercial and consumer relationships are very different," 214 partially because of "the unequal bargaining power of

Florencia Marotta-Wurgler, "Does Contract Disclosure Matter?” (2012) 168:1 J Institutional \& Theoretical Economics 94 at 168.

This is effectively the holding of the Ontario Superior Court in Rudder v Microsoft Corp (1999), 2 CPR (4th) 474 [Rudder] (in which the Court upheld the validity of a click-wrap agreement attached to Microsoft software, including its forum selection clause).

Aleecia M McDonald \& Lorrie Faith Cranor, "The Cost of Reading Privacy Policies" (2008) 4:3 I/S: J Law \& Policy for Information Society 543 at 565 (concluding that in order to read every privacy policy to which he or she is bound, the average American Internet user would have to spend 201 hours a year). See e.g. Rudder, supra note 208. See also Renée Zmurchyk, "Contractual Validity of End User Licence Agreements" (2006) 11:1 Appeal 57; Roger E Schechter, "The Unfairness of Click-On Software Licenses" (2000) 46 Wayne L Rev 1735.

2017 SCC 33, 411 DLR (4th) 434 [Douez].

RSBC 1996, c 373.

Douez, supra note 211, Karakatsanis, Wagner, and Gascon JJ.

Ibid at para 33 . 
the parties and the rights that a consumer relinquishes under the contract, without any opportunity to negotiate." ${ }^{215}$ It also recognized that walking away from every standard form contract is not realistic, especially when it is required to access a service as important to social and political life as Facebook. ${ }^{216}$ Unfortunately, the lead judgment did not consider these concerns relevant to whether a valid contract had been made, but rather treated them as public policy concerns that can render an otherwise enforceable forum selection clause unenforceable. Limited as they were to a test unique to forum selection clauses, it remains to be seen whether this approach can also be applied to other terms in standard form contracts.

By contrast, the concurring judgment of Justice Abella held that the forum selection clause was unenforceable on broader contractual grounds. Indeed, in addition to public policy grounds for non-enforcement, she found the term to be unconscionable. ${ }^{217}$ To her, the question was "[c]an it realistically be said that the consumer turned his or her mind to all the terms and gave meaningful consent?"218

Were Justice Abella's judgment to be followed, it would give strong support to the contention presented here: that the non-core terms of standard form contracts are unenforceable by virtue of the inability of consumers to rationally consider their own interests with respect to the agreement. Indeed, it would appear to be another application of precisely the analysis offered in the discussion of unconscionability, above. But although Justice Abella's judgment does not carry the day, even the lead judgment gives some credence to the notion that standard form contracts are deficient.

Treating standard form contracts as largely unenforceable is undoubtedly controversial. Standard form contracts are widely used, ${ }^{219}$ and it is often presumed in economic literature that they save the drafters significant costs that may then be passed on to the consumer. ${ }^{220}$ Others have argued that even if most consumers are unsophisticated, even a small group of sophisticated consumers will be sufficient to lead the market towards better boilerplate, thus making boilerplate a matter of public choice. ${ }^{221}$ It has been argued that these contracts may not be "contracts" in the normal sense of the term, but should rather be seen as a part of the product, no different from any other characteristic of the product over which the consumer has no say, and about which the consumer has little information. ${ }^{222}$

\footnotetext{
Ibid.

Ibid at para 56.

Ibid at para 112 .

Ibid at para 99.

Slawson, supra note 81 (writing in 1971, Slawson noted that "[s]tandard form contracts probably account for more than ninety-nine percent of all the contracts now made" at 529). See e.g. Robert A Hillman \& Jeffrey J Rachlinski, "Standard-Form Contracting in the Electronic Age" (2002) 77:2 NYUL Rev 429 at 437-38; Trebilcock, supra note 18 at 414-15. University Press, 1997) at 119-20; Alan Schwartz \& Louis L Wilde, "Intervening in Markets on the Basis of Imperfect Information: A Legal and Economic Analysis" (1979) 127 U Pa L Rev 630; Baird, supra note 199 at 936. 
Unfortunately, these arguments have clear problems. The first two fail for lack of predictive power: the (albeit limited) empirical evidence available appears to refute them. Indeed, with respect to EULAs, one study found no correlation between the competitiveness of the market and the consumer-friendliness of terms offered by firms in that market. ${ }^{223}$ This finding suggests that not only is the notion of the sophisticated consumer driving competition unsupported, it also suggests that competition plays little role in the drafting of boilerplate whatsoever. Prices are likewise unrelated to boilerplate: the same study found that prices were on average 34 percent lower in competitive markets than in non-competitive markets, but the boilerplate terms remained approximately the same. If boilerplate did affect pricing, we would expect to see firms that lowered their pricing in competitive markets offset some of that price decrease by increasing the pro-firm nature of their contractual terms, or some firms compete by keeping their prices higher while making their terms more consumerfriendly. Given that neither was observed, it seems unlikely that fine print terms have much bearing on price.

The third argument — that boilerplate can be seen as a product attribute — has more merit. Indeed, the analysis presented in this article suggests that standard form contracts, to the degree they can be called contracts, are almost universally voidable. By treating them instead as a disclosure of a product attribute, we might find another method by which they might continue to be enforceable without upsetting contract doctrine. Of course, this is not currently the approach endorsed by the courts, but it is a worthwhile one to explore. As one of its primary advocates acknowledges, this might give rise to significant regulation. ${ }^{224}$ Indeed, in my view, if we accept the notion that standard form contracts are really a disclosure of product attributes, then we should be willing to accept regulation as detailed and comprehensive for boilerplate terms as we have for other products. Thus we might expect an entire complex regulatory regime, comparable perhaps to food safety law or electronics safety regulations, clearly setting out standards and rules for what can and cannot be included in boilerplate. Regulations might require certification of boilerplate by licensing bodies. Indeed, existing product certification organizations, such as Underwriters Laboratories, ${ }^{225}$ might even get into that business. Standards-setting organizations may form and publish formal standards of compliance.

I suspect that advocates of the view that boilerplate is just a product attribute do not very much like these suggestions. These suggestions seem like they might significantly increase costs to firms and serve to standardize boilerplate, thus taking it out of the competitive arena. But unfortunately, advocates for the product attribute model, in for example, comparing boilerplate to hidden computer components, ${ }^{226}$ conveniently neglect the voluminous 
regulatory and testing requirements such components must meet before they are put into a computer. ${ }^{227}$ Nonetheless, perhaps this model is best.

However, for so long as boilerplate is considered to be within the confines of contract law, the same considerations as apply to every other contract must prevail. In that sense then, these agreements are typically unfair in the sense that they prevent consumers from rationally considering their interests, and should be voidable at the consumers' option. If this test were to be accepted and firms wish to escape that result, they might consider ensuring that consumers are actually apprised of both the terms and their meaning, although this seems untenable given the length and complexity of such agreements. On the other hand, firms might reduce the length of their contracts, and clearly explain any special terms that go beyond the basic price, product, and quantity terms of the transaction. Or they might simply accept the voidability of their agreements.

In either case, the analytical model presented in this article assists in highlighting the problems with contractual boilerplate in a manner that corresponds to the other, and accepted, doctrines of fairness. In so doing, it provides a powerful tool for examining boilerplate and its potential solutions.

\section{Conclusion}

This article has argued that contract law is best viewed as operating at an aggregative and societal level in order to maximize aggregate welfare. As the maximization of welfare is premised upon the parties to an agreement being able to rationally protect their own interests, it stands to reason that, as a general principle, parties should be excused from a contract where it can be demonstrated that one or more of the parties was not able to rationally consider its own interests in the circumstances. Such an inquiry should address all factors, including cognitive biases, external pressures, lack of information or knowledge, the terms of the transaction, the degree of the unevenness of contractual terms, and whether the plaintiff was able to obtain independent legal advice. Due to the dangers and costs associated with undermining the certainty of contractual enforcement, where only one party was unable to consider her interests, a further requirement must be that the defendant knew or should have known that the plaintiff was not in a position to protect her interests.

In most cases, this test will accord with the existing doctrines of fairness, allowing it to provide both explanatory power to doctrines such as mistake, undue influence, unconscionability, and standard form contracts, while simultaneously discarding much of the ambiguity in which those are mired. In this sense, this article does not advocate for a major change to the existing substantive law in that it maintains the concept and effect of existing fairness doctrines, but suggests that these doctrines can be combined and simplified.

227 For example, in Ontario, all consumer electronics for retail sale must include a recognized certification mark that indicates the item has been tested for compliance with the relevant regulations and codes, including the Ontario Electrical Safety Code, O Reg 164/99. Similar requirements exist across the United States and Canada. 
However, where existing law appears inconsistent with these doctrines, such as in the case of standard form contracts, it does suggest some controversial changes. Regardless of any such changes, and most importantly, this article advocates that the right questions be asked when determining issues of contractual fairness.

It may be said that the analysis leaves a wide range for judicial discretion in deciding cases. This is true, but I doubt that it is very much different from the discretion already available to judges in deciding issues of fairness. It does, however, have the advantage of unifying the doctrines and directing judicial analysis towards protecting societal welfare at an aggregate level. Such an approach, therefore, simultaneously follows from a first principles approach to contract law, has the power to explain doctrines of fairness in contract, and can unify those doctrines into a singular, although perhaps broad, analysis. 
[this page is intentionally blank] 